\title{
International Business Research on Transition Economies
}

\author{
Meyer, Klaus E.
}

Document Version

Final published version

Publication date:

2000

\section{License \\ CC BY-NC-ND}

Citation for published version (APA):

Meyer, K. E. (2000). International Business Research on Transition Economies. CEES, Copenhagen Business

School. Working Paper / Center for East European Studies. Copenhagen Business School No. 32

Link to publication in CBS Research Portal

\section{General rights}

Copyright and moral rights for the publications made accessible in the public portal are retained by the authors and/or other copyright owners and it is a condition of accessing publications that users recognise and abide by the legal requirements associated with these rights.

\section{Take down policy}

If you believe that this document breaches copyright please contact us (research.lib@cbs.dk) providing details, and we will remove access to the work immediately and investigate your claim. 


\section{CEES}

Working Paper No. 32

April 2000

\section{International Business Research on Transition Economies}

Klaus E Meyer

\section{Center for East European Studies}

Copenhagen Business School 


\title{
International Business Research on Transition Economies
}

\author{
Copenhagen Business School \\ Center for East European Studies \\ Working paper no. 32
}

April 2000

\begin{abstract}
Klaus E. Meyer
Center for East European Studies, Copenhagen Business School

Howitzvej 60, 2000 Frederiksberg, Denmark

km.cees@cbs.dk - www.econ.cbs.dk/institutes/cees/staff/meyer.html
\end{abstract}

This working paper reviews the literature in the field of international business that is concerned with business in the transition economies in Eastern Europe, as well as literature in related fields that is of pertinent interest to international business scholars. It has been written in preparation of a chapter for the Oxford Handbook of International Business, edited by Tom Brewer and Alan Rugman (OUP: 2001). It contains more material than can be included in the final handbook chapter.

This work benefitted from discussions with colleagues direct and indirect ways. I thank Alan Rugman for initiating this work, and Tom Brewer, Klaus Uhlenbruck, Snejina Michailova as well as other contributors to the handbook for their helpful comments. Specially thanks go to Arnold Schuh (Vienna) for his help with the marketing literature.

Other contributors to the handbook:

Mira Wilkins, John Dunning, Peter Buckley and Mark Casson, Jean-Francois Hennart, Alan Rugman and Alain Verbeke, James Markusen, Stephen Kobrin, Deborah Spar, Steve Guisinger, Sylvia Ostry, Tom Brewer and Stephen Young, George Yip and Stephen Tallman, Richard Hodgetts and Regina Greenwood, Julian Birkinshaw, Andrew Inkpen, John Cantwell, Mike Kotabe, James Dean and Mike Bowe, Lorraine Eden, John Graham, Eleanor Westney, Robert Grosse, John Child, Gordon Redding, Bruce Kogut. 


\section{International Business Research \\ on Transition Economies}

1. Introduction

2. Microeconomic Transition

2.1. New Institutions: New Capitalism?

2.2. From plan to market: change of co-ordination mechanism

2.3. Privatisation and Corporate Governance

2.4. Organisational Transformation

2.5. Entrepreneurial Firms

3. Strategies of Multinational Businesses

3.1. Motivations for being active in CEE

3.2. Entry Strategies

4. Management Challenges

4.1. Privatisation acquisition

4.2. Knowledge transfer and managerial learning

4.3. Managing cultural diversity

5. Outlook 


\section{Introduction}

Until 1989, the countries of the Soviet bloc traded primarily in autarky from the world economy. The small volumes of East-West business were conduced on the basis of counter-trade negotiated with state-trade monopolies (e.g. Neale and Shipley 1990). Only few Western businesses operated within the region, including Occidental Petroleum and Great Northern Telecom (Jacobsen 1997) who offered services considered vital by the socialist leadership.

The revolutions of 1989 brought dramatic changes for existing business relationships (e.g. Salmi and Møller 1994) and opened major business opportunities for the first time since respectively 1917 in Russia and 1945 in Central Europe. The region from Prague to Vladivostok embarked on reform from similar starting positions and with comparable objectives, yet with increasingly divers development since ${ }^{1}$. The transition economies in Central and Eastern Europe (CEE) become similar to other medium-income market economies, while most successor states of the Soviet Union are lagging especially in building market-oriented institutions.

The international policy framework evolved very favourably for international business, with rapid reduction of trade barriers and liberalization of foreign investment regulation. Membership in international organizations, such as WTO, facilitated this process. The westernmost countries signed 'Europe Agreements' with the European Union that further reduced trade barriers vis-a-vis the union, and becane stepping stones towards eventual membership in the union [e.g. Lavigne 1998].

Western businesses were quick to position themselves in the new markets, as is illustrated by the acceleration of foreign direct investment (FDI) in the region, ${ }^{2}$ see Figure 1, and the dramatic reorientation in the pattern of international trade (EBRD 1999). However, businesses operating in the region face a distinct institutional environment, which pre-determines the strategic opportunities for businesses (Peng 2000, Hoskisson et al. 2000). This creates challenges for managers of both local firms and Western business partners that differ not only from Western experience, but also among transition economies. On the other hand, outward international business from the region has been slow to evolve, and rarely been studied (but see Svetličič et al. 1999). However, the comparison with China or Latin America (Child 2001, Grosse 2001) suggests that it will be of increasing importance in the near future.

International business research has so far focused on Western multinational firms operating in the region. Research have approached the transition economies in different ways:

- by testing the validity of general theories in the specific context of transition, and

- by exploring and explaining the specific features of the business context and their implications for business operating in the region. 
The former is prominent in leading management journals, and offers insights for those pursuing development and refinement of theory in their respective fields. The latter research is generally more exploratory and generates novel insights on the functioning of business in transition economies, and theoretical frameworks to analyse it. It contributes to our understanding of the interaction between firms and their environment, which in turn can stimulate research on the relationships between firm behaviour and institutions in mature market economies. This review focuses on challenges faced by businesses in the transition context drawing upon research beyond mainstream business journals.

This review is structured as follows: section two summarises the microeconomic aspects of economic transition, taking the development of new institutions as starting point as they set the stage for developments in the enterprise sphere. The third section discusses multinational firms entering the region, considering their motives, and their strategies to deal with the specific context. Section four addresses some managerial challenges that arise for multinational firms operating in the region. Section five concludes with perspectives for future research.

Figure 1: FDI in selected transition economies

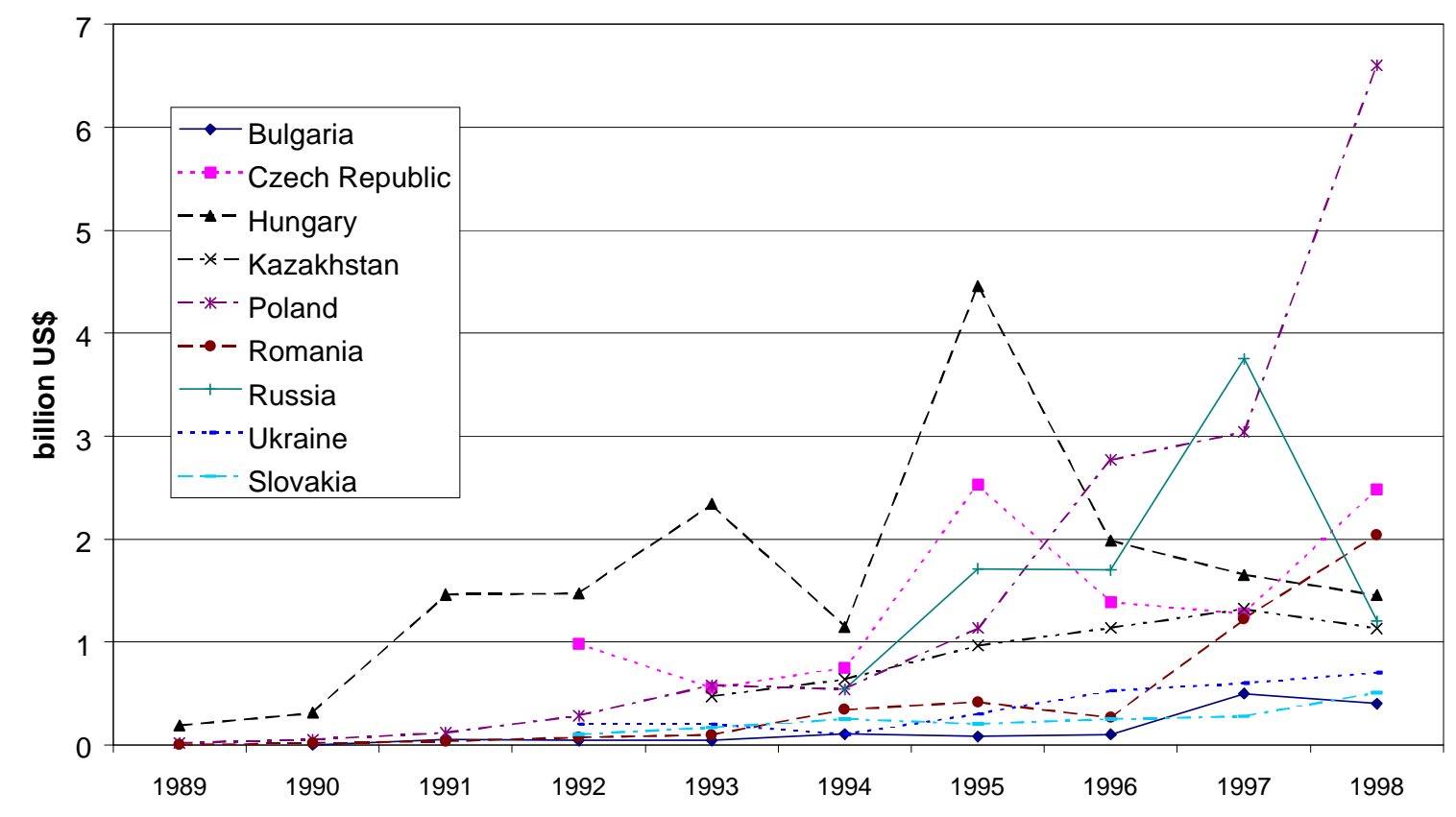

Note: net inflows recorded in the balance of payments, source: EBRD 1999, table 3.1.6. 


\section{Transition}

\subsection{New Institutions: What Kind of Capitalism?}

The essence of economic transition "from plan to market" (World Bank 1996) is the replacement of one set of institutions governing economic activity by a different one. Institutions, albeit frequently neglected in economic theorising, have an essential role in setting the 'rules of the game' by which individuals interact in a market economy (North 1990). They ensure the competitiveness of markets, for instance by preventing or regulating monopolies, insider trading and negative externalities. Only with a solid framework set by institutions does the free interaction of agents lead to efficient allocation of goods and services.

The Western market economies have built their institutions over decades, if not centuries, and they vary as a result of both different historical evolution and underlying cultures (North 1981). The institutions are supported by strong and impartial states, e.g. as guarantors of law enforcement and an independent judiciary. The path dependency of institutional frameworks let to a variety of 'business systems' that differ not only between the US, Asia and Europe but even within Western Europe (Whitley, ed. 1992).

Eastern Europe is building its institutions under strong outside influence, especially from the Anglo-Saxon sphere. Yet, new institutions cannot be superimposed from above as they must meet not only an efficiency test, but also be socially acceptable (Offe 1995). The distinct cultural and systemic inheritance influences especially informal institutions such as norm and values. In addition, the political development during the early years of transition influenced the way new institutions have been set up, notably the methods of privatisation (Stark 1992, Hare et al. 1999). Policy choices made during the period of radical change around 1990 created institutions and established distribution of power. In many countries, the weak legal framework permitted a large extent of opportunistic behaviour, rent shifting, bribery and corruption (e.g. Nelson et al. 1998). In some countries, vested interests have been created that would not benefit from further reform (Stiglitz 1999, EBRD 1999). Due to path dependency of institutions, policies during that 'window of opportunity' and the inheritance from the previous regime shape the future institutional frameworks (North 1990, Stark 1992). Consequently, we can predict that Eastern Europe may develop a distinctive form of capitalism.

In the 1990's, the institutional frameworks were unstable and rapidly changing. The fundamental change in the environment may prompt an expectation of equally radical change of behaviour, but this did not happen in many CEE organisations (Whitley and Csaban 1998a). Even where formal institutions were established quickly, e.g. by copying laws from elsewhere, informal institutions are slow to evolve. Consequently, the process of building institutions in transition economies takes more time than most reform scenarios envisaged in 1990 (Murrell 1992, Kogut 
1996). During this process, agents face the additional challenge that they cannot base their decisions on present institutions, which are unstable, and possibly inconsistent. Flexibility and shortterm objectives should thus be the norm.

The distinctiveness of the CEE business systems, be it temporary or permanent, limits the transferability of Western business strategies and organisational concepts. Hence, strategies observed in transition economies differ from those in developed economies (Peng and Heath 1996), and strategies applied successfully in one country may fail in another. Corporate strategies in the transition economies can thus be explained only by incorporating the specific institutional context in the analysis. This hold for China (Peng 2000, Child 2001) as well as for Hungary or Russia. Some generalizations across these countries may be helpful, yet one has to be cautious as the variation among transition economies may be just as large as that between transition and mature market economies. The following sections review the evolution of the enterprise sector in this context, starting with the central institution of the market economy - the market.

\subsection{From Plan to Market: Change of Co-ordination Mechanisms}

During socialism, the central plan was the core institution co-ordinating economic activity. The societies thus had strong vertical co-ordination, but failed, among other, because horizontal linkages between firms were weak (Vlachoutsicos 1998) leading to high transaction costs between enterprises within supply chains (e.g. Chikan 1996). In addition, the plan focussed on quantitative output targets with few incentives for quality and customer service.

The main purpose of transition was to introduce markets as more efficient co-ordination mechanisms. Yet, the old economic system disintegrated before the institutions supporting a market economy were in place. The absence of, among other, systems providing information, accounting and auditing as well legal enforcement of contracts allowed extensive information asymmetries and opportunities for opportunistic behaviour, thus increasing transaction costs (Swaan 1997). The politically motivated push towards creating markets before creating institutions (Hare et al. 1999) has been especially drastic in the areas of capital markets. Mass privatization quickly brought firms on the stock exchanges, notably in the Czech Republic. Yet as institutions were not in place, this led to multiple opportunities for abuse by insiders, and in fact very slow restructuring of enterprises (Spicer et al. 2000).

In particular, the lack of informal institutions such as routines, knowledge and procedures at the individual and organizational level provoked market failure. Essentially, administrators had to act as independent economic agents from the day the central plan was dissolved. They had to act on markets that did not yet exist; they lacked the (often tacit) knowledge on how to use the market mechanism, and who potential partners and competitors are. Without experience, they had to identify potential types of business and preferences of customers; and they had to assess the 
composition of demand and supply, and estimate demand elasticity. Thus, agents engaged in considerable search processes to set up transactions and to find the right prices (Swaan 1997).

The lack of institutions increases transaction costs, especially for new business relationships, and thus inhibits many potential transactions, in particular those of complex or long-term nature. The resulting co-ordination failure has been a major cause of the deep recession of the early 1990's (Blanchard and Kremer 1996, Swaan 1997). The most visible consequence of failing markets is the widespread use of barter in several successor states of the former Soviet Union (Gaddy and Ickes 1998, Commander and Momsen 1999, Seabright 2000). Yet it also affects international businesses with the transition economies. Western MNEs lack information on their partners; have to negotiate with persons inexperienced in business negotiations (Antal-Mokos 1998); and confront unclear regulatory frameworks, inexperienced bureaucracy (Thornton and Mikheeva 1996) and the weak enforcement of property rights.

The weaknesses of market institutions, and constraints on internalizing transactions, led to the widespread use of alternative, intermediate mechanisms of exchange through informal networks in CEE (Stark 1996, Clark and Soulsby 1995, Todeva 2000), and even more in Russia (Puffer et al. 1996, Holden et al. 1998, Salmi 1996, 1999). The post-socialist economies inherited systems of personal networks that served to overcome shortage under the central plan. These networks connected firms to authorities, especially the communist party and the plan ministries, and focussed on influencing plan targets and delivery of crucial inputs.

The central plan regime created large interdependent production units. They were split into separate enterprises, but retained a high degree of asset specificity and resource dependencies. Many firms reacted by recreating inter-firm relationship by informal means to establish industrial groups (Stark 1996, Hayri and McDermott 1998). In Hungary, Stark (1996) observed 'recombinant networks' of firms with interlocking ownership and other formal and informal arrangement between related companies. In Russia financial-industrial groups developed close ties with banks and political institutions and became significant power bases. Where conventional strategies of internal or external growth are inhibited because the markets for relevant resources are defunct, 'network-based growth strategies' offer an alternative (Peng and Heath 1996). Businesses react to imperfect markets by network-based co-ordination.

Informal networks have retained their importance as a co-ordination mechanism, due to structural and cultural characteristics. However, they do not necessarily reflect the needs of a market economy. Many focus on extraction of rents from the state through collusion between businesses, and between business and units (or individuals) of the government, in particular municipal authorities. The close personal relationships of individuals in different positions frequently give rise to business practices that violate Western standards of business ethics (Puffer and McCarthy 1995, Ledeneva 1999). 
In a market economy, networks also serve an important role in relating interdependent business and overcoming various market imperfections (Axelson and Easton 1992, Mattson 1993). Yet clear legal and ethical codes prevent transactions that cause harm to third parties. Restructuring the networks to serve the needs of a market economy is thus an essential component of transformation.

\subsection{Privatisation and Corporate Governance}

Enterprises in socialist countries had been set-up to achieve the objectives defined by socialist ideology and the central plan, notably the fulfilment of quantitative plan targets. The transition places enterprises at a different place in society, redefining the purpose of their existence. This change involved a formal, legal change and an informal, internal transformation. This section reviews the changes in formal structures through privatisation and systems of corporate governance, and the next section discusses the organisational transformation.

Privatisation in transition differs from Western experiences by the scope of the task, the absence of efficient capital markets, and the lack of private domestic savings that could be invested. These obstacles were overcome by novel routes of privatisation, most notably mass privatisation based on voucher schemes. More conventional modes included direct sales to outside investors, management-employee-buy-outs, and restitution to former owners (Brada 1996, World Bank 1996, Bornstein 1997).

Privatisation is, however, not a sufficient condition to trigger enterprise restructuring. Many privatisations other than by sales to outside investors failed to create powerful incentives that would guide managers in transforming firms. Therefore corporate governance has become the most debated issue in the transition economics literature (e.g. Frydman et al. 1997, La Porta, Lopez-deSilanes and Shleifer 1999, Estrin and Wright 1999). The collapse of communism left state-owned firms without mechanisms for the state to enforce control, and weak internal structures to handle the new demands of the marketplace.

Frequently, managers and/or worker councils attained considerable influence, de facto or de jure, especially in Poland and many CIS countries. In many cases, insiders managed to convert their de facto control into formal ownership by opting for privatisation modes that gave them preferential access to shares. As a result, many firms, particularly in Poland and the former Soviet Union, have managers and employees as minority or even majority shareholders (e.g. Åslund 1995, Blasi et al. 1995). Therefore, theories considering stakeholders, rather than solely shareholders, have been revived to analyse corporate governance in transition economies (Buck, Filatochev and Wright 1998, Berglöf and von Thadden 1999, Mygind 1999).

Corporate governance problems also arose as a result of voucher privatisation. Most transition countries (with the notable exception of Hungary), have implemented a voucher scheme 
as a main pillar of their mass privatisation (e.g. World Bank 1996, Estrin and Stone 1996). It permitted the creation of widespread popular ownership of industrial equity and the redistribution of the wealth to citizens in a 'fair' way, thus generating popular support for reform. The Czech scheme - the first and most publicised - privatised a major share of the country's assets in several waves of multiple-auction bidding processes. Investment funds attained considerable power through the accumulation of vouchers and bidding on behalf of individuals (Coffee 1996). They now control major Czech businesses, but themselves are often owned by (largely state owned) banks. This creates interdependent institutions without clear monitoring and control structures, but with multiple agents that have hold-up power (Hayri and McDermott 1998). The resultant lack of effective corporate governance has frequently been blamed for the slow progress of enterprise restructuring (e.g. Nellis 1999).

In Poland, the large privatisation was delayed due to political conflicts over its conditions. In 1996, shares of some 500 enterprises were allocated to government-sponsored investment funds, which in turn were privatised through vouchers that are now traded on the Warsaw stock exchange. Each enterprise was initially owned by a fund holding 33\% of equity, plus minority shareholdings by the other funds, workers, and the government. While overcoming defaults of corporate governance in the Czech voucher privatisation, the Polish scheme still suffers from conflicts between different control institutions. In Russia, mass privatisation has been rapid and created a substantial private sector - but dominated by insider ownership (e.g. Boyko et al. 1995, Blasi et al. 1997, Earle and Estrin 1997, Wright et al. 1998, Estrin and Wright 1999). The resulting management and employee ownership may have positive effects on motivation and labour productivity (Ben-Ner and Jones 1995), but can be a major obstacle for restructuring in large firms, if lay-offs or access to outside finance are required. ${ }^{3}$

Following privatisation, the emergence of local equity markets is crucial. The need to raise fresh capital should induce insider-controlled firms to accept new outsider equity stakes and provide acquisition opportunities. However, progress has been slow (Earle and Estrin 1996, Filatochev et al. 1996) and ownership patterns are relatively stable (Jones and Mygind 1999a, Anderson et al. 1999). Especially in the former Soviet Union, it is difficult to obtain ownership and effective control of privatised firms, among other because stock market institutions such as protection of minority shareholders are not in place.

However, competition is at least as important as privatization for enterprises to improve their efficiency - a result fully consistent with empirical research on privatization in the West (e.g. Vickers and Yarrow 1991). Yet while many major Western privatisations are industries with natural monopolies that require complex regulation to create competition, most firms privatized in Eastern Europe enjoy monopoly powers courtesy of past or present government policy. After privatization, the key difference is "not how competition affects firm performance, but in the degree to which 
market forces in transition are either softened or distorted" (Bevan et al. 1999:14). Firms in transition frequently face soft budget constraints and obtain protected market positions of various sorts. In Russia, a particular problem appears to be the lack of domestic entry, and thus contestable markets, in part due to protective intervention by regional authorities (Broadman 1999). In other countries, such as Poland, new entrants are a major source of competition (see Section 2.5).

Thus the transition economies are poised to retain corporate governance systems that differ from those in mature market economies, even taking into account the variation found for instance between the US and Continental Europe. Some of the largest firms in the region are subject to weak governance while enjoying close contacts to government and, in some ex-Soviet Union states, considerable barriers to entry. Yet other firms have gone very far in shedding these legacies of the $20^{\text {th }}$ century. This diversity of governance mechanisms and of competition patterns is likely to be a continuing feature of the region for years to come.

\subsection{Organisational Transformation}

In the socialist regime, firms' overriding objective was plan-fulfilment. ${ }^{4}$ The incentives created by central planning led however to severe distortions, such as the production of large volumes of standardised low quality products, lack of concern for consumer demand, disregard for externalities of any kind, notably for the environment. By establishing positions rather than creating jobs, firms employed far more people than necessary to achieve their output target as labour costs were not a constraining variable. Employment relationships were effectively based on life-time employment and enterprises provided many of the social needs of both current and retired employees. The enterprise sector was reasonably efficient in allocative efficiency, but failed dramatically in innovation (Berliner 1976, Murrel 1990, Kogut and Zander 2000). In this system, management had few incentives, or in fact opportunities, to act as business leader or entrepreneur in a Western sense.

As this brief characterisation makes clear, firms have a very different role in socialist and in capitalist societies (Heidenreich 1993). Consequently they have different resource configurations, skill and capability reservoirs, and ways of organising themselves. As transformation involves all these areas - and I do not content this would be a complete list - it is a complex task.

It typically started with defensive adjustments aimed at survival under hard budget constraints, e.g. laying off workers or shifting the product mix (see reviews by Brada 1996, Carlin 2000, Bevan et al. 1999 and EBRD 1999). Productivity improved, even before privatisation, as management reacted to external pressures. However, further strategic and organisational restructuring is necessary to attain sustainable competitiveness (Meyer 1998b). Few domesticowned firms have been able to pursue corporate strategies that would lead to a viable position in the international competition (Brada 1996, Wright et al. 1998, Stiglitz 1999). Foreign-owned firms 
engaged in more strategic change such as development of new products, investment in new production facilities, entry into new markets and establishing marketing, new brand names and distribution channels (e.g. Carlin et al. 1995, Estrin et al. 1997, Newman and Nollen 1998, Djankov 1999a, Hooley et al. 1996).

At the onset of transition, many advisors focussed on productivity improvements, promoting redundant assets and downsizing to reduce over-employment. However, excessive reliance on cost cutting has been criticised for undermining firms' ability to develop new strategies. A certain degree of slack can be an important resource for innovation (Nohria and Gulati 1996), for managerial learning (Geppert 1996) and thus for transformation. Many firms undoubtedly had excess slack. However, some firms, notably in East Germany, seem to have cut the workforce to such extent that the moral was undermined, and no slack left that could become a source for new growth (Thomson and Millar 1999).

Beyond downsizing, the re-configuration of resources needs a pro-active approach to acquiring complementary resources, through both investment in complementary assets and organisational learning (Uhlenbruck and Meyer 2000). Especially in the area of marketing, firms have to improve their basic competences in terms of structure, systems and processes, organizational culture and human resources (Batra 1997). The learning begins with top managers, who are often not well prepared to lead the transformation process. Many essential management capabilities were not developed under socialism because other skills were asked for. Managerial learning (see Section 4.2) and employee training thus are crucial elements of the resource upgrading.

These organizational changes arise not only from the change of economic system, but also from the methods of organising production. The labour process in the socialist period was designed on Taylorist principles, with high degrees of division of labour and technical job specialisation, and close supervision. Yet, the frequency of distortions in supplies, inadequate machinery and to some extent shortage of skilled labour made the full realisation of the cost advantages impossible. As Taylorism has been the norm of industrial production in the 1950s, but passed into history in most sectors in industrial countries, it was expected that transition would instigate the shift to postTaylorist production (Sorge 1993, Meyer and Møller 1998). Yet evidence from Hungary shows that in some firms, notably locally owned ones, the opposite occurred. Firms refined their 'scientific management' and reduced costs by more precise division between skilled and unskilled workers and more rigorous supervisory control. In the short-term, these firms showed above average productivity and profitability (Whitley and Csaban 1998b, Taplin and Frege 1999). Yet it is doubtful if such a strategy will enhance competitiveness in the longer term.

Also in other empirical evidence points to continuity rather than radical change. Observing 27 Hungarian case firms, Whitley and Csaban (1998a) conclude that by most criteria, they showed 
a remarkable degree of continuity, for instance in terms of product mix, production technology, and markets. Although top management had often been replaced, the new leaders were typically promoted internally. Interdependence led firms to continue existing relationships rather than to seek business opportunities with different partners (Stark 1996, Todeva 2000). The continuity of personnel, the persisting importance of the political environment and limited role of product market competition contributed to continuity in management strategies and behaviour (Martin 1999, Newman and Nollen 1998).

This continuity is natural, according to the evolutionary view of transformation. Resource re-configuration requires the acquisition of new capabilities, which have to be developed from existing ones, in combination with imported know-how. Organizations thus evolve, rather than reincarnate themselves overnight, when facing change - even radical change - in their environment. Consequently, Spicer, McDermott and Kogut (2000) are concerned that privatization was too radical and broke up existing industry networks and thus inhibited the effective use of cospecialised resources. Kogut (1996) recommends that firms ought to learn through experimentation and internal development of new routines and capabilities adapted to the specific context, rather than the wholesale imposition of imported routines. Lieb-Dóczy and Meyer (2000) suggest that especially foreign acquirers risk losing valuable local capabilities if they concentrate on transfer of their established best practice and neglect development of variety by fostering indigenous capabilities.

In conclusion, ET and the ensuing managerial challenges are complex phenomena that cannot be analyzed satisfactorily with established theoretical frameworks only. Having reached the limits of conventional economic analysis, further analysis may extend the resource-based view of the firm to explore specific challenges of emerging and transition economies (Hoskisson et al. 2000). I see potential in complementing this perspective with organizational learning theory (Uhlenbruck and Meyer 2000), evolutionary theory (Lieb-Doczy and Meyer 2000) or theory of coordination games (Meyer 2000c) to analyze the changing resource base during ET.

\subsection{The Growth of Entrepreneurial Start-ups}

Despite the major efforts in privatisation, much of the recent economic growth in the transition economies comes from newly established firms. Especially in Poland, the new private sector is flourishing while much of the former state-sector is stagnating (e.g. Johnson and Loveman 1995, EBRD 1999). These new firms are often the most dynamic units in the region. Some new private firms arose from the liquidation of state-owned firms, as individuals or groups of managers or workers acquired the assets. Other start-ups grew out of the informal grey economy. Peng (2000) points to four groups of individuals that become entrepreneurs by setting up their own businesses in transition economies: 
- $\quad$ Scientists and other professionals pursue entrepreneurial activity in reaction to the rapid decline in real income at their job in the public sector or a privatizing firm. Often this starts as part-time job, notably for academics seeking to better their income through consultancy (Webster and Charap 1993, Kirby et al. 1996).

- $\quad$ Former cadres frequently become entrepreneurs especially in Russia, capitalizing on their control over key resources, including physical and financial assets, and most importantly network connections to the bureaucracy (Rona-Tas 1994, Parish and Michelson 1996).

- Individuals who were left at the bottom of society after losing their previous position may survive as street trader, and gradually upgrade to bazaar trader, and to shop ownermanagers. They thus mature from the grey economy to the official economy.

- $\quad$ Farmers may have enjoyed private ownership of their plots, as in Poland, which provided them with initial resources for entrepreneurial activity in related sectors.

The pressure of enterprise transformation created strong push factors for specialists to leave the uncertainty of a privatizing firm, and seek their own fortune. Many, however, retain close business relationships with their former employer, more than spin-offs in the West typically do (Kirby et al. 1996). Entrepreneurial firms thus grow as part of the new corporate networks in the region (Stark 1996). They are joined by managers who attained control, with our without formal ownership, over privatized enterprises.

The newly established businesses benefit, compared to privatized ones, from simple governance structures, low fixed costs, and flexibility to switch from unpromising markets to more attractive ones (Johnson and Loveman 1995, Puffer et al. 2000). Moreover, without the burden of inheritance from a predecessor organization, entrepreneurs have the freedom to hire selectively the most suitable employees. In the early years of liberalisation, many newly established firms were extremely profitable, in part because they offered products not previously available, or served niche markets, and second-movers were slow.

However, the opportunities for entrepreneurs are often constrained by their lack of resources and by the institutional context. Financial resources have been a major constraint for many given the underdeveloped capital markets (Holmström 1996, Johnson and Loveman 1995). Venture capital funds have only recently been established in the region and are gradually developing expertise in assessment and monitoring of entrepreneurial firms in the transition context (Karsai et al. 1997). Yet equally important are human capital as well as political and social capital, i.e. access to key decision-makers in politics and business (Batjargal 2000).

Institutional change permitting the establishment of new businesses and simplifying licensing procedures was the starting call for entrepreneurship. Yet obstacles in the institutional framework are still the main hindrance for further development of entrepreneurial firms, especially 
in the less advanced transition economies. This includes high informal barriers to entry, weak protection of property rights, excessive bureaucracy, and corruption. For instance, newly established firms pay on average over 5\% in 'bribe tax' compared to around $4 \%$ for privatised and state-owned firms (EBRD 1999). Johnson, McMillan and Woodruff (1999) found that reinvestment of profits has been especially constrained by the weak protection of property rights. Moreover, entrepreneurs continue to be obstructed by a weak investment climate and indirect barriers to entry (EBRD 1999, Broadman 1999).

Entrepreneurship research on transition economies stands - unless major contributions have escaped my attention - very much at the beginning. ${ }^{5}$ However, it ought to be as important as the transformation of existing SOE for the future of these economies, as well as for Western businesses looking for suitable partners in the region.

\section{Strategies of Multinational Businesses}

\subsection{Motivations}

Theoretical research has pointed to the importance of factor cost advantages (e.g. Ozawa 1992), as has a comparison of CEE with East Asia (Urban 1992, UN 1995, Meyer 2000b). FDI was expected to utilise factor differences and to build export oriented production. CEE still has low labour costs compared with Western Europe although higher than some locations in Southeast Asia. Factor cost advantages may also arise from low cost of locally extracted raw materials.

However, there is almost undisputed evidence that markets are the main attraction of the region, as reported in the large number of surveys conducted among Western firms with investments in CEE and among joint-ventures within the region (e.g. Meyer 1998a, Pye 1998, OECD 1995, Lankes and Venebles 1996). Many MNEs considering entry expect considerable long-term growth of demand, especially as the income of the middle class, their prime customers, grows faster than the average measured by GDP (Batra 1997). Several features make the markets in CEE particularly attractive (Estrin and Meyer 1998):

First, consumers in CEE had previously had little or no access to consumer goods and brands available in other countries at similar levels of per capita income. Trade liberalisation unleashed a catch-up demand, especially for consumer durables for which West European markets are saturated. The high status of Western goods was in part a result of Western media penetration, even before 1989. It was sustained through effective advertising and brand-building in the newly liberalised local media.

Second, entry in CEE may be a strategic move by MNEs to sustain or enhance their global strategic position. Global leaders may invest to prevent challenges from their rivals or the emergence of new competitors from within the region. Firms dominated by a larger competitor may 
see early entry in new markets as an opportunity to gain competitive advantages. MNEs established in both Western and Eastern Europe may have superior opportunities to exploit price discrimination, product differentiation or vertical integration. In industries with major network externalities, such as consultancy and financial services, presence in the region may be necessary to offer global coverage for their globally operating customers.

Third, several underdeveloped sectors of industry are being reestablished to accelerate productivity growth across the economy. Governments in CEE are therefore inviting foreign investors to upgrade telecommunications, power-generation and distribution, and transportation infrastructure. They encourage selective private entry, e.g. licensing of new service providers or concessions to operate existing public infrastructure (EBRD 1996). In addition, the privatization of utilities, especially in the telecommunications sector, attracts substantial FDI capital inflows, which explains some of the volatility of FDI flow data (Figure 1). The infrastructure development creates furthermore opportunities for those providing inputs, such as construction firms, turnkeyplant engineers, and manufacturers of telecommunications equipment.

Factor cost oriented FDI has picked up since the early 1990s. While fewer in number, this includes some high profile FDI projects and substantial capital inflows. Many projects may initially have focussed on local markets, but as these were saturated and productivity in the new affiliate increased they started exporting to other nodes in the investors' multinational network.

CEE has comparative advantages in intermediate technical skills as the level of technical education in the region was relatively high, although it has considerably deteriorated since 1990, at least in Russia (Clarke and Metalina 2000). At the same time, unit labour costs have risen substantially but are still significantly below West European, especially German, levels. Economic policy has strengthened this advantage in some countries through an effective undervaluation of exchange rates or incomes policy, such as constraints on wage increases. FDI can utilize the lower costs by combining it with Western capital and managerial skills.

Low factor costs attract especially SME and firms from the neighbouring countries who exploit the cost differential through outward-processing with or without equity investment. The relocation of production has been important is a small number of industries including textiles, clothing, furniture or musical instruments. It gained in relative importance in the mid 1990's as costseeking investors were under less time-pressure than market-seekers.

However, many cost-oriented investors were deterred by low productivity, lack of telecommunication and transportation infrastructure, and bureaucracy (OECD 1995, Meyer 1998a, Pye 1998). In addition, investors face obstacles in identifying suitable local partners and suppliers able to provide inputs and services at the required level of quality.

\subsection{Entry Strategies}


Since most Western businesses entered the region only in the 1990s, CEE provides an excellent laboratory to study international business entry. Entry strategies encompass a number of interrelated strategic variables, however, researchers have preferred to analyse the different components separately, and so will this review. Firstly, there are locational choices, which have been discussed in the previous section. Secondly, entrants select an entry mode, such as export, contractual co-operation or FDI. Direct investors furthermore have to decide the share of their equity ownership, and whether to invest in a greenfield project or by acquiring an existing firm. Third, the timing and speed of entry is crucial for instance for those pursuing first-mover advantages. Moreover, a successful entry requires an appropriate strategy for marketing, e.g. branding of products, and for human resource management.

\subsubsection{Entry Mode Strategies}

The choice of entry mode soon became a foremost research topic of IB scholars interested in Eastern Europe (e.g. Brouthers et al. 1998, Meyer 1997, 1998a, Ali and Mirza 1996, Pye 1998). Initially, entrants preferred modes with low exposure to country risk, especially exports and contracting. Ten years into the transition, this still applied in some countries of the former Soviet Union, but less in Central Europe. Most businesses started with exporting, but accelerated relatively quickly to contractual and investment modes. Many firms moved quickly along the internationalization process, some even establishing FDI in their firstly activity (Engelhard and Eckert 1993, Ali and Mirza 1996, Czinkota et al. 1997).

Contractual modes were particular important before legal constraints had been fully removed, and when investment risks were perceived to be high. Beyond the standard forms, this included for instance management-, technology- and turnkey-contracts. Franchising became popular as eager local entrepreneurs looked to franchisers to provide them with both resources and managerial training. At the same time, those managing global brands found franchising a fast way of expansion while limiting their investment risk. Subcontracting has been particularly popular with German and Italian SMEs relocating selected stages of their production process (Naujoks and Schmidt 1994, Pellegrin 1998). New contractual arrangements have been developed to facilitate the region's infra-structure investments. For instance, build-operate-transfer contracts permit private investment and ownership, yet with ultimate transfer to the public sector.

\section{Ownership of FDI}

In the early 1990s, a JV was the only legally permissible mode to establish a direct investment (OECD 1995, Hood and Young 1994, Hunya 1996). Yet, the ownership patterns have been rapidly changing since then. Regulations have been relaxed in many small steps, and by 1992, FDI was 
fairly unregulated in most countries (EBRD 1994), though it took far longer in Russia (McMillan 1994).

This explains the initially high share of joint-ventures, and the massive shift towards fullyowned affiliates in the mid 1990's as both new investors and by old investors increasing their equity share (Sharma 1995). Many acquisitions in the privatization process occurred in a staggered pattern, and were thus registered as JV although from the beginning the investor attained management control and envisaged the acquisition of full ownership (Perotti and Gulati 1993, LiebDóczy and Meyer 2000). These 'transitory alliances' (Hagedorn and Sadowski 1999) are means of implementing acquisitions in a particular institutional context, and share little of the characteristics typically observed in joint-ventures (cf. Beamish and Killing 1997). As temporary arrangement they offer advantages to both partners. Governments obtain some control over the firm's restructuring, and thus externalities created for the local economy, while capitalising on the probable appreciation of the share value as the transition economy becomes less uncertain (and avoid embarrassment over initial underpricing). Governments may also be reluctant to transfer control over firms deemed strategic, or trading with governmental institutions (Wright et al. 1993) for both political and economic reasons. The investor obtains access to local institutions and networks while sharing investment risk.

Investors normally aim for full control of acquired businesses, not only to reduce transaction costs but to be able to enforce faster turnaround of former state-owned enterprises (Aulakh and Kotabe 1997). However, many entrants, at least initially, accept lower degrees of involvement. A local partner may be useful in many ways, notably in accessing local business and government networks. Especially in Russia, such informal networks are vital for business, substituting many functions of the institutional framework in mature market economies (Thornton and Mikheeva 1996, Puffer et al. 1996, Holden et al. 1998). Consequently, entry modes with higher capital commitment are preferred in the advanced transition economies, while low risk modes are employed in markets that are still unstable or lacking a reputable institutional framework.

Formal tests of the determinants of entry modes mostly find support for the same factors as studies elsewhere, especially with respect to firm and industry specific variables, thus confirming the validity of the respective theoretical framework. For instance, Brouthers et al. (1998) showed the influence of cultural attributes of both home and host country, in addition to cultural distance. CEE-specific aspects emerge with the factor endowment of the local economy and the institutional framework, which influence the transaction costs in pertinent markets and thus investors' internalization preferences (Meyer 1998a).

The performance of FDI has been analyzed on the basis of survey data, e.g. in Hungary (Lyles and Baird 1994, Meschi 1997), Russia (Fey 1995, Thornton and Mikheeva 1996) and Kazakhstan (Charman 1998). The success of a JV depends mainly on issues such as the 
compatibility of the objectives of the parents, and establishment of mutual trust while avoiding of dominant control by either partner. International business experience of the local partner is important, as is the Western partner's management training. In Russia, reputation effects and selfenforcing contracts are important to overcome the weaknesses of the institutional framework (Thornton and Mikheeva 1996). However, wholly owned operations are judged to perform better in investors' own assessment (e.g. Lyles and Baird 1994).

\section{Acquisition or Greenfield}

Foreign investors wishing to establish a wholly-owned operation could often do so only through an acquisition in the privatisation process. This, however, requires complex negotiations with multiple governmental authorities (Brouthers and Bamossy 1997, Antal-Mokos 1998, Marinova 2000) as well as with management and work councils (Bak and Kulawczuk 1997). Moreover, the investor has to take responsibility for enterprise transformation (cf. Section 3), and may face considerable post-acquisition investment in resource upgrading and organisational change while being constraint by stipulations of the privatization contract (see Section 4.1).

As this post-acquisition investment often exceeds the initial investment, the project takes on features normally associated with greenfield investment, and clearly different from conventional acquisitions. Such 'brownfield' investment (Meyer and Estrin 1999) can substitute for both greenfield strategies where crucial local assets are not available in unbundled form, and for acquisition strategies where the resources of local firms are to weak to face international competition.

Investors prepared to commit to enterprise restructuring and technological upgrading, find acquisitions attractive to access valuable human capital in local firms, especially their technological skills, and to (informal) local networks and to government agencies. Local brand names and distribution networks are also valuable assets in some consumer goods industries. Acquirers furthermore report fewer bureaucratic obstacles to acquiring land and obtaining the permits required to start or expand production (Meyer and Estrin 1999).

Despite these advantages, investors increasingly bypass the restructuring of local firms and set up greenfield operations. This allows them to implement their corporate strategy without having to incorporate the heritage of an acquired firm. Small firms that lack the managerial and financial resources to lead enterprise restructuring, are even more avoiding acquisitions in the privatization process (Estrin and Meyer 1998). Consequently, the share of greenfield investment is increasing in CEE, in contrast to world-wide trends.

\subsubsection{Strategies for Timing and Acceleration of Entry}


Many MNEs in industries with world-wide oligopolistic structures were among the first entrants (Marton 1993, Kogut 1996). They pursued first-mover advantages that are perceived to be very important in consumer goods industries where brand names are crucial competitive assets (e.g. Arnold and Quelch 1998). Expected long-term benefits include brand recognition, control of distribution channels, and preferential access to local suppliers and governments. One way to attain such advantages is to acquire the dominant local firm in the industry. Moreover, early entrants may even be able to influence the local regulatory environment in their favour. The perceived importance of first-mover advantages is highlighted by Lankes and Venebles (1996) who report a bimodal distribution on the first-mover motive: very important for 39\% of investors, especially for those targeting the local market, but unimportant for most others.

Is this euphoria about first-mover advantages justified? Liebermann and Montgomery (1998) cast doubt on the first-mover argument by showing that product innovators rarely became market leaders. An optimal product specification and a marketing strategy to penetrate a mass market are more important for lasting success. The entry in Eastern Europe poses slightly different challenges as the products in question are at mature stages of their life cycle and their marketing methods have been tested elsewhere. Even so, first entrants have to overcome obstacles in the local environment, and strategic decisions on e.g. location and partner choice incur considerable sunk costs. Moreover, brand names may be worth less where brand loyalty is low as consumers still experiment with new products. Case evidence suggests that some first-movers failed to realize their expected benefits, and second-movers could build a larger market-share or a more profitable operation (Meyer and Estrin 1998, Bridgewater et al. 1995).

Later entrants benefit from local bureaucrats' improved understanding of the needs of business, and from first-movers' investment in training and introduction of new types of products to 'build the market'. 'Fast-seconds' can learn from successes and failures of the first-mover and adapt their strategies for marketing and government relations accordingly.

Aiming for the best of both strategies, many investors followed a foothold strategy that provides an entry to the market, but delays commitment of substantive capital investment. Such 'platform investment' (Kogut 1983), e.g. a representative office, permits the investor to learn about the local environment while investigating business opportunities. The local base permits a rapid response to emerging business opportunities. Such foothold strategies were important for the first investors in Hungary (Marton 1993) and in the volatile environment of Russia (Fey 1995).

Some authors have developed more detailed typologies of strategies that they observed in Eastern Europe (Hooley et al. 1993, McCarthy and Puffer 1997, Bridgewater et al. 1995). By distinguishing entrants by their strategic investment motives and the speed of resource commitment, they observe some noteworthy strategies: 
Many investors are client-followers in that they enter Eastern Europe to serve customers they have served before (Bridgewater et al. 1995). Their investment decisions are thus linked to the strategies of major customers. This applies in particular in the automotive industry (v.Tulder and Ruigrok 1998, Meyer 2000b) and in the financial sector, but also ordinary products such as cola can draw bottling companies and manufacturers of modern packaging to the East. The client provides a sufficiently large and secure demand to merit the commitment, and from that base the follower may expand onto the local market. Last not least, many Western businesses such as accountants and consultants supply projects funded by Western agencies such as the EU (Gilbert 1998).

Investors in the oil and gas industry face heavy up-front investment, especially for extraction and refining (McCarthy and Puffer 1997). The sector attracts a major share of FDI in Russia and her neighbours to the South, but investors have to be cautious not only because of high sunk costs, but because they need to cooperate closely with key local players in governments and among state-owned or privatized monopolies. Investment consortia between major multinational are thus common, both to share the risk of mega investment projects, and to negotiate with the authorities.

\subsubsection{Marketing Strategies}

Beyond entry mode choice, marketing scholars have addressed issues of market penetration, consumer behaviour and marketing management (see Schuh and Springer 1997 for a review). A major concern are the trade-off between standardization and differentiation. Batra (1997), and Arnold and Quelch (1998) recommend a multi-tier product strategy to serve not only the high-end segments but also the middle and lower price segments of the markets. They suggest that foreign companies should adjust their product mix to the purchasing power given the low average household income in these countries. Adaptation of consumer electronics, for example, may stripout of existing sophisticated products those features - with the corresponding costs - that are not highly valued yet, and provide products that are more reliable and need less servicing (Batra 1997).

However, empirical research suggests that foreign investors typically position their products at the upper end of the market, leaving the lower end to local brands, in anticipation of market growth with the emergence of the middle class (Schuh 2000). Many of the first entrants were global-oriented companies that create products pro-actively and adapt them passively, pursuing highly standardized marketing strategies in CEE with limited adaptation e.g. of labelling, package design and brands (e.g. Church 1992, Hooley et al. 1993). Classic country-related differentiation can only be found in the consumer goods industry and is often connected to the acquisition of local companies (Dahm, 1995). In fact, several incidences have reported that investors discontinued an acquired local brand, but later re-introduced after realizing the loss of the 
mass market (Meyer and Estrin 1998, Lieb-Dóczy 2000). Regional management centres play an important role in bridging to gap between globalization and local market responsiveness by selecting the products for in the region, and coordinating marketing strategies for several countries (Schuh, et al. 1995).

Research into marketing mix and distribution channels points to major challenges for multinational entrants. Distribution channels are often fragmented, with small retailers accounting for a large share of consumer markets. Reliable marketing information is scarce. Channels of mass communication are less developed and less effective where consumers prefer to rely on personal experiences. This suggests a need for high distribution intensity and multiple marketing partners rather than exclusive distributors. Extensions of successful brands ("Umbrella branding") and multi-tier product strategies to cover high- and middle-price segments of market have proven to be successful. However, consumers are very price sensitive such that markets tend to be price competitive. TV and event sponsorship are reported to be most effective to establish brand names if used considerate to local cultural, political and religious sensitivities (e.g. Shama 1992, Batra 1997, Arnold and Quelch 1998).

Consumer behaviour has been volatile and varying across the region, making it hard to give definitive answers on issues such as buying behaviour, attitudes to country of origin and impact of advertising. Most marketing researchers essentially benchmark CEE against the West thus failing to address issues of specific relevance to countries in transition (Schuh and Springer 1997). Future research may thus pay more attention to issues such as national marketing systems, specifics of marketing in CEE by country and industry, marketing at different stages of enterprise transformation, and establishment of effective marketing institutions and networks in CEE.

Reviewing the marketing literature, one notices a variety of innovative strategies proposed. Yet few authors provide convincing evidence of superior performance of the strategies. Counter-intuitive evidence, such as first-mover failures, suggest caution. Future research may focus more on the long-term performance implications.

\section{Management Challenges}

Western businesses operating within transition economies face a number of specific challenges that arise from the transition context. In this section, we look in particular at the implications of running a formerly state-owned firm, knowledge transfer, managerial training, and cultural diversity within the organization.

\subsection{Privatisation Acquisition}

Owning and managing a privatized business unit confronts businesses with national politics. From the investor's perspective, it is a case of 'mergers and acquisitions', yet buying a firm from the 
government results in a number of peculiarities. Privatization aims to break the link between governments and firms. Yet, the political social and economic context of privatisation constrains post-privatisation strategies (Uhlenbruck and DeCastro 2000):

- Government sell firms not only to maximise their financial revenues, but to pursue broader social objectives (e.g. Estrin 1994). The corporate strategy pursued by the (formerly) state-owned firm is interdependent with other aspects of public policy. For instance, the divestment of social assets (kindergartens, health care facilities, etc) is interdependent with the ability of other providers, municipal or otherwise, to provide these services. Layoffs are constrained by the social consequences of unemployment.

- The negotiation process is complicated not only by the broader set of objectives of the seller but by the multiplicity of interest groups involved in the process and by the relative inexperience by the local negotiators (Antal-Mokos 1998). Brouthers and Bamossy (1997) and Arens and Brouthers (1999) analyse the role of the government using the concept of the 'key stakeholder'.

- After completing the sale, governments often continue to be indirectly involved with the privatised firm. They can create tools to control the actions of the acquirer as an agent by extending the contract beyond outright sales. This occurs in CEE through retained minority shareholding, conditions imposed on the acquirer (Stark 1992, Uhlenbruck and DeCastro 1998), and competition policy. At the same time, governments may support privatised firms by securing financing, guarantee procurement, tax breaks, restrictions on import competition etc. (EBRD 1994, 1999).

Especially 'staggered divestment' (Perotti and Guney 1993) allows privatization agencies a temporary and limited degree of influence on post-acquisition management. If the acquirer attains management control, the influence of the government on operational management is limited. The foreign investor may not like the possible government interference in strategic decisions, but would appreciate the risk sharing and the lower amount of capital to be raised at the outset. Furthermore, the interests of the government, especially regional or local authorities, are becoming more aligned with those of the business if they share the profits of the venture. This should reduce undue bureaucracy and regulatory interference, while providing access to important local networks.

One might expect weaker performance of firms in mixed ownership because the government may aim at obtaining social rather than financial returns. At the same time, the private partner faces weaker incentives arising from the lower share in profits, and may benefit from some form of transfer pricing. (The MNE has to share any profit of the JV, but keeps all if it is accounted for elsewhere). Compared to local firms, economic studies do not show better performance for JV 
than for local firms, as would be expected given their more proactive restructuring (Section 2.3). Managers themselves assess performance of firms with residual government ownership more negatively (e.g. Lyles and Baird 1994). However, Uhlenbruck and DeCastro (2000) find that firms with residual state-ownership actually perform better in terms of sales growth.

With the acquisition the investor takes responsibility for the enterprise transformation process. This requires substantial additional investment in upgrading of equipment, organizational restructuring and training. Foreign acquirers thus face an uphill struggle, although compared to local firms, they have a number of advantages:

- $\quad$ They have access to complementary resources, in particular finance and managerial knowledge.

- $\quad$ They can establish clear control structures, and thus avoids most of the corporate governance problems associated with other forms of privatisation in CEE.

- $\quad$ They can better initiate organisational change through the experience in leading competitive businesses and thus providing and vision and a strategy for the restructuring

- $\quad$ They can create market access by integrating the acquired business into their international production networks (Schwartz and Zysman 1998, Meyer 2000a).

The importance of investing in the acquired business is illuminated not only by the frequency of brownfield investment in the region (Meyer and Estrin 1999), but by the fact that investment is the only strategic variable that Uhlenbruck and DeCastro (2000) and others found clearly associated with better performance. Also research on joint-ventures suggests that support from the foreign partner is crucial (Lyles and Baird 1994, Lyles et al. 1996, Fey 1995).

Investors find it difficult to create both 'strategic fit' as market-oriented operations are created from pure manufacturing firms, and 'organizational fit' as organisational cultures differ due to different historical experiences (Uhlenbruck and DeCastro 2000). The investor thus has to create a comprehensive strategy for the post-acquisition restructuring and integration (Obloj and Thomas 1998, Meyer and Møller 1998, Thomson and McNamara 1998). A central part of this strategy is the learning process of the local organisation.

\subsection{Managing the Learning and Education Process}

Firms have to upgrade their managerial capabilities far more fundamentally than is catered for by conventional management training. Technological skills were on a high level due to good general education in natural sciences, especially mathematics and engineering. Yet managerial and social skills were deficient due to both the change of skills and capabilities required in the new institutional setting, and the separation from modern social sciences. Incumbent leaders were often 
insufficiently prepared as they had different tasks and developed other skills in the central plan system. In fact the required capabilities are often beyond the experience-horizon of individuals used to the central-plan system. What is worse, the new private sector in Russia makes very little provision for training of their employees, while locally available training is limited and relatively expensive (Clarke and Metalina 2000). The required new skills are often based on tacit know-how, which requires an interactive learning process (Swaan 1997). They can be described in three levels (Child 1993, Villinger 1996):

- $\quad$ At the technical level, new and specific techniques have to be acquired such as methods for quality measurement, scientific and engineering techniques or the construction of samples for market research.

- $\quad$ At the systemic level, new systems and procedures have to be adopted, which requires integrative learning emphasising co-ordination, relationships and links. Examples include co-ordination of integrated production systems, or production control and budgeting systems. Already at this level, the learner not only has to unlearn acquired routines and replace them by new ones, but to reassess attitudes and value systems underlying behaviour within the organisation under the old and the new regimes (Michailova 1997, Meyer and Møller 1998).

- $\quad$ At the strategic level, senior managers have to change their cognitive framework for doing business and conducting the tasks of management. They need to reassess their criteria of business success and factors contributing to that success. This requires understanding of technological and managerial processes in such depth that they can engage in innovation, select and adapt technology and take strategic decisions.

The acquisition and adaptation of this complex, and in many cases tacit, knowledge is inhibited by the cultural and institutional context of its transfer (Jankowicz 1994, Kostera and Wicha 1996, Geppert 1996). Managerial learning, and in particular the internalisation of new knowledge, is modified by the connection made by recipients between new ideas, information and experiences and their prior knowledge and experiences. The content of received knowledge is filtered through the mind set of the recipient in CEE and their experiences in the socialist society (Soulsby and Clark 1996).

Most academic observers therefore stress the need to contextualize the contents and methods of training in Eastern Europe (e.g. Jankowicz 1994, 1996, Child and Czekledy 1996). Yet, a fundamental discrepancy separates Western training methods, which are grounded in extensive research, and the expectations of Eastern course participants. The contextualisation of training programs thus faces the dilemma that formalisation of delivery methods, as preferred by many 
participants, cannot achieve the objectives of the training, i.e. inducing managers to think for themselves on a strategic level (Hollinshead and Michailova 1999).

Those transferring management knowledge to the East often took, especially in the early 1990 's, an ethnocentric perspective, believing in the superiority of the Western way of doing things and being disrespectful, or unaware, of local traditions, cultures and accomplishments (Hollinshead and Michailova 1999). Western consultants in particular are resented, delivering reports of little practical use because they fail to understand the institutional context of the CEE firms (Soulsby and Clark 1996). This led to considerable 'consultancy fatigue' (Gilbert 1998) especially if the consultants obtain only superficial information on the ground and, as they are paid for by international institutions, are more concerned about Brussels or Washington than with Novgorod or Vladivostok.

This literature advises to employ individuals that relate modern management and postcommunist reality. For instance, Soulsby and Clark (1996) report that local consultants with Western training and émigrés returning to their roots have been highly appreciated by local managers. In Central Europe, the intellectual and cultural gap between Western and local managers is narrowing, yet finding persons capable of communicating effectively in the former Soviet Union is still a considerable challenge.

Vlachoutsicos and Lawrence (1996) argue that positive change in managerial practice will come about only if continuities with the values and decision-making processes of the Russian traditional collective are preserved, and the natural behaviour of Russian managers are integrated into newly-introduced managerial systems and practices. From the perspective of evolutionary and institutional economics, new practices have to be build on existing attitudes and value systems, preserving selectively what is worthy, and using experimentation to discover new best practices suitable for transition economies (Kogut 1996, Spicer et al. 2000). JV research confirms the importance of incorporating local management as 'shared management' is generally associated with better performance (Lyles and Baird 1994, Fey 1995).

The evolutionary development of capabilities is however challenged by the radical nature of the organisational change faced by many firms. The turbulence, the dramatic shortfall of available resources, and the fundamental threats created for many people has inhibited, if not undermined, their willingness to learn (Hedberg 1991, Villinger 1996). In the face of high uncertainty imitation of imposed practices may be preferred to an internalisation of new knowledge (Child and Czegledy 1996). Newman and Nollen (1998) thus observe an inverse-U shaped relationship between firms' ability to learn and to restructure and the gap between existing and required capabilities. This suggests that training should be based on a step-wise learning process, with clearly delimitated intermediate targets. 


\subsection{Managing Cultural Diversity}

Western investors managing acquired businesses or joint-ventures in transition economies experience considerable cultural diversity, and consequently conflicts between different groups within the organization (e.g. Child and Markoczy 1993, Puffer and McCarthy 1997). Managing such conflicts of organisational culture is a major challenge for joint-ventures, especially in Russia (Puffer et al. 1996, Michailova 2000, Fey and Beamish 1999). As Russian culture is often seen as not conducive to successful market-based management, managers, as well as researchers, face a major challenge in how to change organizational culture (Fey and Denison 1999). Yet what are the origins of such cross-cultural conflicts?

\section{The cultural legacy of socialism}

The business culture in transition economies is in flux, and therefore hard to define. Three distinct cultural forces are, in a way, battling for the hearts and minds of East European people. These are firstly the historical cultural roots that have been loosened, but not lost with the arrival of socialism. Secondly, the socialist experience bears upon those who grew up under the system. Thirdly, many people are willing to shed either legacy to adapt Western culture, or what is received of it through the media, business contacts and tourists. Thus, culture is unusually unstable and shows considerable discrepancies between the cultural norms and behaviours communicated in public and those people actually internalized (Todeva 1999). Feichtinger and Fink (1998) describe the volatility of culture in the 1990 's, and the corresponding confusion at the individual level, as 'collective culture shock'. This analogy suggests that after a period of disorientation, the societies will recover and prosper with the new cultural identity. In the Western parts of the region, culture is converging to West European patterns, with regional specialties such egalitarian and religious values.

Socialism left behind a 'bloc culture' (Sztompka 1993). This is not the officially propagated philosophy of Marxism-Leninism, but the reality of values and attitudes of individuals within real existing socialism. Despite the communitarian ideology, socialist regimes were low-trust regimes. Distrust was institutionalised through networks of informers of KGB or its partner institutions, fostering suspicion even when it was without foundation. In consequence people drew a sharp separation between their private and public circles. As a double legacy of socialism, "individuals are likely to have a high degree of trust in their immediate social network, and a high degree of distrust in the formal institutions of the state" (Rose et al. 1997:10). Low levels of trust in institutions continue in the transition period, reinforced by insider privatization that benefited the old nomenklatura, the growth of the Mafia, and corrupt politicians. Transition thus has to build trust in institutions, beyond the personal level. 
Russian business culture has however roots that go deeper than socialism. Several researchers aim at explaining this culture and the emerging cross-cultural discrepancies in RussianWestern organisations (Lawrence and Vlachoutsicos 1990, Puffer et al. 1996, Michailova 2000, Holden and Cooper 1994, Holden et al. 1998, Kets de Vries 1998, Elenkov 1998). Vlachoutsicos (1998) presents a comprehensive analysis of 'the inner logic of Russian management' based on its roots in both Russian history and the influences of 70 years of socialism. He outlines the 'matrioshka' structure of Russian organisations with strong vertical ties, but weak horizontal coordination, and the traditional decision making process. This is typically top-down on strategic matters, but contains a major consultative element on issues of implementation, if only in a ritualised fashion.

These traditions influence perceptions of Russian managers' by their Western counterparts. For instance, Russians are reported to act short-term orientated, averse against planning, and they typically expect the leaders to take strategic decisions, but discuss methods of implementation (Michailova 2000). Yet there is considerable variation of behaviour and belief systems between, say, a Soviet-area senior executive and a young entrepreneur (e.g. Puffer et al. 1997).

\section{Networking}

Bonding and other forms of network activities have a central role in Russian business. They arise from both cultural traditions and as substitute to legal institutions such as contract enforcement. East European managers are well versed in developing personal business networks, and in making informal arrangements to compensate for the breakdowns in formal resource allocation and distribution systems (Child and Czegledy 1996, Martin 1999). At least the former is, while commonly overlooked in economic models, is an important part of business in any economic system, and fostered in modern management under the title of the 'network organization'.

In Russia, networking occurs more at a personal level activity rather than between institutions. Several studies emphasise the importance of personal relationships as Russians typically do not distinguish between personal friends and business relations (Kets de Vries 1998, Salmi 1999, Meyer et al. 1999). Social activities thus are part of business dealings. This arises from cooperative value systems, distrust towards strangers, and traditions such as blat (Ledeneva 1999). To overcome initial mistrust, Russians are reported not to engage in business before they have shared social activities, and substantial amounts of vodka. Western partners are expected to participate in such bonding activity (Holden et al. 1998).

The reliance on informal relationships raises pertinent issues of business ethics for local and in particular foreign business persons operating in the region. The emphasis on connections may undermine the introduction of new and objective standards of performance by creating distrust 
and dissatisfaction (Cyr and Schneider 1996). Moreover, there is a thin line between networking and unethical or illegal activity. Russians consider for example violation of insensible laws as normal, yet can it be for a Western investor? It may be infeasible to do business if one was to obey all the rules at all times (Puffer and McCarthy 1995). Experienced investors say that there are ways to cope with the situation, e.g. by building contacts at highest level in the authorities, by knowing the law precisely, and by exchanging experiences with other Western expatriates. Yet, Russia is not for beginners.

\section{Communication}

A challenge that is often underestimated by Western expatriates is the communication across cultural and linguistic divides (Villinger 1996, Cyr and Schneider 1996, Jankowica 1994). Effective communication is important to convey to the entire workforce the strategic direction of the business, to obtain direct feedback, and to build personal relationships and trust. It requires that both partners are sensitive to each others cultural and historical context and share a common language (Villinger 1996, Michailova and Anisimova 1999, Michailova 2000). Learning on local business conditions is particularly important in transition economies because of their distinct history, traditions and economic structures which feed contemporary culture.

Many Western MNE operating in CEE invest in training their Eastern workforce in the company language, typically English or German, yet few expatriates learn local languages (Villinger 1996, Michailova 2000). This is seen with some resentment by local employees, and can create considerable misunderstandings as translators are naturally imprecise notably for business terminology where English terms do not have precise equivalents in Slovonic languages (Hollinshead and Michailova 1999). In addition, the communication has to overcome the culturallyconditioned differences in key concepts such as 'time', 'plan' and 'control' (Michailova 2000), which is a particular serious problem in Slavonic languages where expressions for certain Western business terminology have not been developed prior to 1990 .

\section{Human resource management}

Human resource management has to accommodate the cultural diversity. An area where this appears particular difficult is the recruitment and remuneration of people for the local operation. Many investors assign expatriates to all top management positions, and aim at recruiting and training local personnel to take over these positions after a few years. This however proved difficult, especially for finance and marketing personnel. The small number of qualified people in these fields, often younger than their Western counterparts, found themselves head-hunted by Western investors. Yet, beyond this small elite, managerial labour markets hardly function at all because of the shortage of key personnel (Peiperl and Estrin 1997). 
Local firms have generally low turnaround of managers. Three years into transition, $78 \%$ of top and second tier management positions in the Czech Republic were still held by former nomenklatura managers. Most changes occurred at the position of the CEO and the personnel managers, often the party representative, who were mostly replaced internally (Clark and Soulsby 1996, Newman and Nollen 1998). Management change is more frequent in firms facing competition and hard budget constraints (EBRD 1999:139) and, where outsiders were recruited, associated with better performance (Claessens and Djankov 1998), suggesting that active recruitment will eventually take hold in the region.

Western HRM approaches have been adopted in the region, for instance by creating a wider spread of salaries (Basu et al. 1997, Clark and Soulsby 1996). Incentive-based pay has been introduced, especially by Western investors, but with mixed success as it sometimes conflicts with the egalitarian local culture (Mueller and Clarke 1998, Cyr and Schneider 1996). As in other areas of management, HRM practice in Central Europe converges towards West European models, while Russians still have a high level of suspicion over the introduction of Western management ideas (Holden et al. 1998, Shekshina 1998). MNEs adopted their HRM policies to the local context to varying degrees. While performance appraisal and promotion were standardized, recruitment, training and financial reward systems were locally adapted, especially in Russia (Björkman and Ehrnrooth 1999). Only some of the HRM policies adapted in Russian firms were found to actually improve performance (Fey et al. 2000).

\section{Perspectives for future Research}

The study of business in transition economies offers opportunities not only to understand 'transition' but to generate insights, concepts and theoretical frameworks for international business in general. The transition economies provide a laboratory for business; and insights gained here will contribute to the discourse on global economy in the $21^{\text {st }}$ century. Research challenges include questions on how business evolve during radical organizational change, and how institutions shape corporate behaviour. Scholars may venture more inductive research, and develop new concepts and frameworks relevant beyond the region.

In the 1990s, research focussed on issues that were specific to the start of transition and the opening to international business. Research needs to move on, from privatization to new entrepreneurial businesses, from entry strategies to operations strategies, and from negotiating acquisitions to managing subsidiaries. Yet this research needs to consider the business context that, as proposed in Section 2.1, has developed specific institutional characteristics that are likely to persist for the next decades.

The analysis of institutions and their influence on corporate strategies and enterprise behaviour can be taken beyond Peng (2000) to explain not only the differences of strategies 
between capitalist and transition economies, but to explain variations within regions. China followed a different path of transition, with gradual reform since the late 1970s, but observers detected interesting similarities with transition in Europe at the level of enterprises (Child and Markoczy 1993, Batra 1997, Peng 2000). Yet researchers need to be cautios about generalizing across emerging economies - as evident from comparing this paper from its companion on China (Child 2001). Challenges faced by enterprises vary considerably due to different macroeconomic and institutional contexts even within the region. Hungary and poland, for example, converge with Western Europe, while Russia will retain distinct features for many years.

For example, the legal-institutional framework cannot yet guarantee property rights, which creates interesting challenges for contracting under uncertainty and without external enforcement mechanisms. Corporate ownership and governance exhibits specific features such as a high share of employee-ownership, staggered privatization, and close relations between businesses and governments. This implies that managers have to pursue profits as well as non-monetary objectives set by the firm's shareholders and stakeholders.

Firms design their corporate strategies and management procedures in response to these institutions, in particular by building business relationships that rely not only on markets as coordination mechanism. Consequently, we observe innovatory strategies such as conglomerate building in form of 'recombinant property' (Stark 1996) and 'network-base growth strategies' (Peng and Heath 1996). Further research may explore in more depth how different institutions influence the design of business organisations. This requires the development of more sophisticated analytical tools concerning the link between institutions and strategy.

Foreign investors too select and adjust their modes of business. They develop new forms of non-equity cooperation, engage in 'transitory alliances' (Hagedorn and Sadowski 1999) and 'brownfield investment' (Meyer and Estrin 1999). Businesses moreover face major challenges in understanding the local business cultures and in developing appropriate approaches to crosscultural management and to change management - areas where applied research could be of great value. Last not least, technological advances may permit the region to leap-frog stages of technological development and innovate business, e.g. in e-commerce.

The analysis of business in an unusual context provides a laboratory to explore aspects that are less observable in mature market economies. Novel concepts and analytical frameworks may feed back into theories used in mainstream international business research. In addition to the institutional perspective, Hoskisson et al. (2000) point to the potential of adapting transaction cost theory and the resource-based view of the firm to the specific challenges of emerging markets. However to enrich these frameworks, researchers have to be venturous in their approaches, and apply exploratory research methods. Existing theory helps analysis by concentrating attention on important variables and relationships - but fails if important variables or relationships are missed. 
Few region specific insights are born out of hypothesis testing of standard theory. We need inductive research to understand new or unconventional business contexts. Longitudinal studies and linkages to related literature in, for example, transition economics and sociology may help to develop new, relevant and dynamic theoretical frameworks.

\section{References}

Ali, Shaukat and Hafiz Mirza (1996): Entry Mode and Performance in Hungary and Poland: The Case of British Firms, Academy of International Business, UK chapter conference at Aston University, March, Proceedings p. 1-23.

Anderson, James H., Georges Korsun and Peter Murrel (1999): Ownership, exit and voice after mas privatization: Evidence from Mongolia, Economics of Transition 7, p. 215-43.

Antal-Mokos, Zoltan 1998. Privatisation, Politics, and Economic Performance in Hungary, Cambridge, CUP.

Arnold, David J., \& Quelch, John A. 1998. New Strategies in Emerging Markets. Sloan Management Review 39(3): 7-20.

Arrow, Kenneth (1985): The Economics of Agency, in: J. Pratt and R. Zeckhauser, eds.: Principals and Agents: the Structure of Business, Boston, MA: HBS Press, p. 37-51.

Arens, Patrick and Keith D. Brouthers (1999): Key Stakeholder Theory and State-owned versus Privatized Firms, London, mimeo.

Åslund, Anders (1995): How Russia become a Market Economy, Washington, DC: Brookings Institution.

Aulakh, P.S. and Mike Kotabe 1997. Antecedents and Performance of Channel Integration in Foreign Markets, Journal of International Business Studies 28, p. 145-175.

Axelsson, B. and G. Easton, eds.: Industrial Networks: A New View of Reality, London: Routledge

Bąk, M. and P. Kulawczuk 1997. Foreign Investment Withdrawals from Poland: Case Studies and Recommendations, mimeo, The Institute for Private Enterprise and Democracy, Warsaw.

Barberis, Nicholas, Maxim Boyko, Andrei Shleifer and Natalia Tsukonova (1996): How does Privatization work? Evidence from Russian Shops, Journal of Political Economy 104, p. 764-90.

Basu, Swait, Saul Estrin and Jan Svejnar (1997): Employment and wage behaviour of Industrial Enterprises in Transition Economies: The Cases of Poland and Czechoslovakia, Economics of Transition 5, p. 271-289.

Batjargal, Bat (2000): The Impact of Resources and Resource Combination on Firm Performance in Russia, mimeo, London Business School, January.

Batra, Rajeev (1997): Marketing Issues and Challenges in Transitional Economies, Journal of International Marketing, 5(4): 95-114.

Beamish, Paul W. and J.P. Killing, eds. (1997) Cooperative Strategies: North American Perspectives, San Francisco: Lexington.

Ben-Ner, Avner and Derek C. Jones (1995): Employee Participation, Ownership and Productivity: A Theoretical Framework, Industrial Relations 34, p. 532-554.

Berglöf, Erik, and Ernst-Ludwig von Thadden (1999): The Changing Corporate Governance Paradigm: Implications for Transition and Developing Countries, mimeo, Stockholm and Lausanne.

Berliner, Joseph S. (1952): The Informal Organization of the Soviet Firm, Quarterly Journal of Economics 64, p. 342-65.

Berliner, Joseph S. (1976): The Innovation Decision in Soviet Industry, Cambridge: MIT Press. 
Bevan, Alan A., Saul Estrin and Mark Schaffer (1999): Determinants of Enterprise Performance during Transition, Working Paper no. 99/03, Center for Economic Reform and Transformation, Heriot-Watt University, Edinburgh.

Blanchard, Oliver and Michael Kremer (1996): Disorganization, Quarterly Journal of Economics 62, p. 1091-1126. Blasi, Joseph, Mava Kroumova and Douglas Kruse (1997): Kremlin Capitalism: Privatizing the Russian Economy, Ithaca: Cornell University Press.

Björkman, Ingmar and Mats Ehrnrooth (1999): HRM in Western Subsidiaries in Russia and Poland, Journal of EastWest Business 5, no. 3, p. 63-79.

Bornstein, Morris (1997): Non-standard Methods in the Privatization Strategies of the Czech Republic, Hungary and Poland, in Economics of Transition 5, no. 2, p. 323-338.

Boyko, Maxim, Andrei Shleifer and Robert. W. Vishny (1996): A Theory of Privatization, Economic Journal 106, p. 309-19.

Brada, Josef C. (1996): Privatization is Transition - Or is it? Journal of Economic Perspectives 10, p. 67-86.

Brewer, Thomas L. (1994): Indicators of Foreign Direct Investment in the Countries of Central and Eastern Europe: A Comparison of Data Sources, Transnational Corporations 3, no. 2, p. 115-126.

Bridgewater, Susan (1999): Networks and Internationalisation: The Case of Multinational Corporations entering Ukraine, International Business Review 8, p. 99-118.

Bridgewater, Susan, R. Kieran and R. Wensley (1995): Strategic Investment Decisions by Western Firms in Ukraine: The Role of Relationships in Home and Host Market Networks, Journal of East West Business 1, 3: 17 - 35

Broadman, Harry G., ed. (1999): Russian Enterprise Reform: Policies to Further the Transition, Washington, DC: The World Bank.

Brouthers, Keith D. and Gary Bamossy (1997): The Role of key Stakeholders in International Joint-Venture Negotiations: cases from Eastern Europe, Journal of International Business Studies 28, p. 285-308.

Brouthers, Keith D., Lance E. Brouthers and George Nakos (1998): Central and Eastern European Investment: A Comparison of U.S., Dutch and German firm activities, in: G. Hooley, R. Loveridge and D. Wilson, eds: Internationalization: Process, Context and Markets, MacMillan Press.

Buck, Trevor, Igor Filatochev and Mike Wright (1998): Agents, Stakeholders and Corporate Governance in Russian Firms, Journal of Management Studies 35, p. 81-104.

Carlin, Wendy (2000): Empirical Analysis of Corporate Governance in Transition, in: E. Rosenbaum, F. Bönker and H.-J. Wagener, eds: Privatization, Corporate Governance and the Emergence of Markets, London: MacMillan, forthcoming.

Carlin, Wendy, Jan van Reenen and Toby Wolfe (1995): Enterprise Restructuring and Dynamism in Transition Economies, Economics of Transition 3, p. 427-458.

Charman, Ken (1998): The Structure and Charactistics of International Joint-Ventures in Kazakhstan, unpublished PhD thesis, London Business School.

Chikan, A. (1996): Consequences of Economic Transition on Logistics: The Case of Hungary, International Journal of Physical Distribution and Logistics Management 16, no. 1.

Child, John (1993): Society and Enterprise between Hierarchy and Market, in: J. Child et al., ed., Societal Change between Market and Organization, Aldershot: Avebury.

Child, John (2001): China, in: Oxford Handbook of International Business, Oxford: OUP, forthcoming.

Child, John and Livia Markoczy (1993): Host-country Managerial Behaviour and Learning in Chinese and Hungarian Joint-ventures, Journal of Management Studies 30, p, 611-631. 
Child, John and Andre P. Czegledy (1996): Managerial Learning in the Transformation of Eastern Europe: Some Key Issues, Organization Studies 17, p. 167-180.

Church, N. (1992): Advertising in the Eastern Bloc: Current Practices and Anticipated Avenues of Development, Journal of Global Marketing 5, no. 3, p. 109-129.

Claessens, Stijn and Simeon Djankov (1998): Managers, Incentives and Corporate Performance: Evidence from the Czech Republic, mimeo, The World Bank, April.

Clark, E. and A. Soulsby 1995. Transforming former state enterprises in the Czech Republic, Organization Studies 16, p. 215-242.

Clarke, Simon and Tanya Metalina (2000): Training in the New Private Sector in Russia, International Journal of Human Resource Management 11, p. 19-36.

Coffee, J.C. Jnr (1996): Institutional Investors in Transitional Economies: Lessons from the Czech Experience, in: R. Frydman, C. W. Gray and A. Rapazynski (eds.): Corporate Governance in Central Europe and Russia, vol. 1, London and Budapest: Central European University Press.

Commander, Simon and Christian Momsen (1999): Understanding Barter in Russia, EBRD Working paper no. 37, December.

Cyr, Diane J. and Susan C. Schneider (1996): Implications for Learning: Human Resource Management in East-West Joint Ventures, Organization Studies 17, p. 207-226.

Czinkota, M. R., Gaisbauer, H., \& Springer, R. 1997. A Perspective on Marketing in Central and Eastern Europe. The International Executive 39, p. 831-848.

Dahm, M. 1995. Strategische Marktbearbeitungsentscheidungen internationaler Markenartikel-unternehmen am Beispiel Ungarns. Der Markt 34, p. 122-132.

Djankov, Simeon (1999a): Ownership Structure and Enterprise Restructuring in Six Newly Independent States, Comparative Economic Studies 41, p. 75-95.

Djankov, Simeon (1999b): The restructuring of insider-dominated firms: A Comparative Analysis, Economics of Transition 7, p. 467-480.

EBRD - European Bank for Reconstruction and Development (annually since 1992): Transition Report, London: EBRD.

Earle, John S. and Saul Estrin (1996): Employee-Ownership in Transition, in: R. Frydman, C. Gray and A. Rapaczynski, eds.: Corporate Governance in Central Europe and Russia, Budapest: Central European University Press.

Earle, John S. and Saul Estrin (1997): After Voucher Privatization: The Structure of Corporate Ownership in Russian Manufacturing Industry, CEPR Working Paper no. 1736, London: CEPR, December.

Elenkov, Detelin S. (1998): Can American Management Concepts work in Russia: A Cross-Cultural Comparative Study, California Management Review 40, no. 4, p. 133-156.

Engelhard, Johan and Stefan Eckert (1993): Markteintrittsverhalten deutscher Unternehmen in Osteuropa, Der Markt Zeitschrift für Absatzwirtschaft und Marketing 32, no. 4, p. 172-188.

Ernst, M., Alexeev, M. \& Marer, P. 1996. Transforming the Core: Restructuring Industrial Enterprises in Russia and Central Europe. Boulder, CO: Westview Press.

Estrin, Saul, ed. (1994): Privatization in Eastern Europe, London: Longman.

Estrin, Saul, Kirsty Hughes and Sarah Todd (1997): Foreign Direct Investment in Central and Eastern Europe, London: Cassel.

Estrin, Saul and Klaus Meyer (1998): Privatization-Acquisition: Who Buys State-owned Enterprises? MOST - Economic Policy in Transitional Economies 7, p. 159-172.

Estrin, Saul and Adam Rosevear (1999): Enterprise Performance and Corporate Governance in Ukraine, Journal of Comparative Economics 27, 442-458. 
Estrin, Saul and Robert Stone: Taxonomy of Mass Privatization, Transition (World Bank), Nov. 1996, p. 8-9.

Estrin, Saul and Mike Wright (1999): Corporate Governance in the Former Soviet Union: An Overview, Journal of Comparative Economics 27, 398-421.

Feichtinger, Claudia and Gerhard Fink (1998): The Collective Culture Shock in Transition Economies - theoretical and empirical Implications, Leadership and Organizational Development Journal 19, no. 6, p. 302-324.

Fey, Carl (1995): Important Design Characteristics for Russian-Foreign Joint-Ventures, European Management Journal 13, p. 405-415.

Fey, Carl F. and Paul Beamish (1999): Strategies for Managing Russian International Joint Venture Conflict, European Management Journal 17, p. 99-106.

Fey, Carl, Ingmar Björkman and Antonia Pavlovskaya (2000): The Effect of Human Resource Management Practices on Firm Performance in Russia, International Journal of Human Resource Management 11, p. 1-18.

Fey, C.F. and D.R. Denison. 1998. Organizational Culture and Effectiveness: The Case of Foreign Firms in Russia, Institute of International Business, Stockholm School of Economics, Research Paper no. 10/98.

Filatotchev, I., Hoskisson, R. E., Buck, T. \& Wright, M. 1996. Corporate restructuring in Russian privatizations: Implications for U.S. investors. California Management Review, 38(2): 87-105.

Fisher, Stanley and Ratna Sahay 2000. The Transition Economies after Ten Years, NBER Working Paper no. 7664 (www.nber.org/papers/w7664)

Frydman, Roman, Cheryl Gray and Andrzej Rapaczynski, eds. (1996): Corporate Governance in Central Europe and Russia, vol. 1, London and Budapest: Central European University Press.

Frydman, Roman, Cheryl Gray, Marek Hasel and Andrzej Rapaczynski (1997): Private Ownership and Corporate Performance: Evidence from Transition Economies, EBRD working paper no. 26, London, December.

Gaddy, C.G and B.W. Ickes. 1998. Russia's Virtual Economy, Foreign Affairs 77, 53-67.

Geppert, Mike (1996): Paths of Managerial Learning in the East European Context, Organization Studies 17, p. $249-268$.

Gilbert, Kate (1998): Consultancy Fatique: Epistomology, Symptoms and Prevention, Leadership and Organizational Development Journal 19, no. 6, p. 340-346.

Grosse, R. (2001): Latin America, in: Oxford Handbook of International Business, Oxford: OUP, forthcoming.

Hagedorn, J. and B. Sadowski. 1999. Exploring the Potential Transition from Strategic Partnering to Mergers and Acquisitions, Journal of Management Studies, January.

Hare, Paul, Judy Batt, Martin Cave and Saul Estrin (1999): Introduction, in: P. Hare, J. Batt and S. Estrin, eds.: Reconstituting the Market, The Political Economy of Microeconomic Transformation, Amsetrdam: Harwood Academic, p. 1-30.

Hayri, Aydin and Gerald McDermott (1998): The Network Properties of Corporate Governance and Industrial Restructuring: A Post-Socialist Lesson, Industrial and Corporate Change 7, p. 153-194.

Hawrylyshyn, Oleh and Donal McGettigan (1999): Privatization in Transition Countries: A Sampling of the Literature, Working Paper of the International Monetary Fund, no 99/6.

Hedberg, Bo (1991): How Organizations Learn and Unlearn, in: P.C. Nystrom and W.H. Starbuck, eds, Handbook of Organizational Design, Oxford: Oxford University Press.

Heidenreich, M. 1993. Vom volkseigenen Betrieb zum Unternehmen: Transformationsprobleme betrieblicher Produkt-, Organizations- und Personalkonzepte in Ostdeutschland, Koelner Zeitschrift fuer Soziologie und Sozialpsychologie 45, p. 46-96.

Holden, Nigel and Cary Cooper (1994): Russian Managers as Learners: Implications for Theories of Management Learning, Management Learning 25, p. 503-22. 
Holden, Nigel, Cary Cooper and Jennifer Carr (1998): Dealing with the New Russia: Management Cultures in Collision, Chichester et al.: Wiley.

Hollinshead, Graham and Snejina Michailova (1999): Blockbusters or Bridge-builders? The Role of Western Trainers in Delivering New Entrepreneurialism in Eastern Europe, mimeo, Bristol and Copenhagen, June.

Holmstroem, Bengt (1996): Financing of Investment in Eastern Europe: A Theoretical Perspective, Industrial and Corporate Change 5, p. 205-237.

Hood, Neil and Stephen Young (1994): The internationalization of business and the challenge of East European development, in: P. Ghauri and P. Buckley, eds: The Economics of Change in East and Central Europe, London: Academic Press.

Hooley, Graham J., Josef Beracs and K. Kolos (1993): Marketing Strategy Typologies in Hungary, European Journal of Marketing 27, no. 11/12, p. 80-101.

Hooley, Graham, Tony Cox, David Shipley, John Fahy, Jozef Beracs and Kristina Kolos (1996): Foreign Direct Investment in Hungary: Resource Acquisition and Domestic Competitive Advantage, Journal of International Business Studies 27, no. 4, pp. 683-709.

Hoskisson, Robert E., Lorraine eden, Chung Ming Lau and Mike Wright (2000): Strategy in Emerging Markets, Academy of Management Journal, forthcoming.

Hunya, Gabor (1996): Foreign Direct Investment in Hungary: A Key Element of Economic Modernization, Research Report no. 226, Vienna Institute for Comparative Economic Studies (WIIW), February.

Jacobsen, Kurt (1997): The Great Northern Telegraph Company: A Danish Company in the Service of Globalisation since 1969, in: S. Tønnesson, J. Koponen, N. Steensgaards and T. Svensson, eds.: Between National Histories and Global History, Helsinki: FHS.

Jankowicz, D. (1994): The new journey to Jerusalem: Mission and meaaning in the man, Organization Studies 15, p. 479-.

Jankowicz, D. (1996): On resistance to change in the post command economies and elsewhere, in: M. Lee et al., eds.: Management education in the new Europe, p. 139-162.

Johnson, Simon, John McMillan and Christopher Woodruff (1999): Property Rights, Finance, and Entrepreneurship, mimeo, MIT and UCSD.

Johnson, Simon and Gary W. Loveman (1995): Starting Over in Eastern Europe: Entrepreneurship and Economic Revival, Cambridge, MA: Harvard Business School Press.

Jones, Derek C., Mark Klinedienst and Charles Rock (1998): Productive Efficiency during Transition: Evidence from Bulgarian Panel Data, Journal of Comparative Economics 26, p. 446-464.

Jones, Derek C. and Niels Mygind (1999a): The Nature and Determinants of Ownershiop Changes after Privatization: Evidence from Estonia, Journal of Comparative Economics 27, p. 422-441.

Jones, Derek C. and Niels Mygind (1999b): Ownership and Productive Efficiency: Evidence from Estonia, Working Paper no. 24, Center for East European Studies, Copenhagen Business School.

Karsai, J., Wright, M., \& Filatotchev, I. 1997. Venture capital in transition economies: The case of Hungary. Entrepreneurship Theory and Practice, 21 (4): 93-110.

Kets de Vries, Manfred (1998): *** (russian culture) ***

Kirby, D. A., Jones-Evans, D., Futo, P., Kwiatkowski, S., \& Schwalbach, J. 1996. Technical consultancy in Hungary, Poland, and the UK: A comparative study of an emerging form of entrepreneurship. Entrepreneurship Theory and Practice, 20 (4): 9-23.

Kogut, Bruce (1983): Foreign Direct Investment as a Sequential Process, in C.P. Kindleberger and D. Audretsch (eds): The Multinational Corporation in the 1980's, Cambridge, MA: MIT Press. 
Kogut, Bruce (1996): Direct Investment, Experimentation, and Corporate Governance in Transition Economies, in: R. Frydman, C. W. Gray and A. Rapaczynski (eds.): Corporate Governance in Central Europe and Russia, vol. 1, London and Budapest: Central European University Press, p. 293-332.

Kogut, Bruce and Udo Zander (2000): Did Socialism fail to Innovate? A Natural Experiment of the Two Zeiss Companies, American Journal of Sociology, forthcoming.

Kornai, Janos 1980. Economics of Shortage. Amsterdam: North-Holland.

Kornai, Janos 1992. The Socialist System: The Political Economy of Communism. Princeton, NJ: Princeton University Press.

Kostera, Monika and Maciej Wicha (1996): The 'divided self' of Polish state-owned enterprises: The culture of organization, Organization Studies 17, p. 83-.

Lankes, Hans Peter and Anthony Venebles 1996. Foreign Direct Investment in Economic Transition: The Changing Pattern of Investments, Economics of Transition 4, p. 331-347.

LaPorta, Rafael, Florencio Lopez-de-Silanes and Andrei Shleifer (1999): Corporate Ownership around the World, Journal of Finance 54, p. 471-517.

Lavigne, Marie (1998): Conditions for accession to the EU, Comparative Economic Studies 40, p. 38-57.

Lavingne, Marie (1999): Economics of Transition, 2nd ed., London: Macmillan.

Lawrence, Paul R. \& Vlachoutsicos, Charalambos A. (Eds.). 1990. Behind the Factory Walls: Decision-making in Soviet and U.S. Enterprises. Boston, MA: Harvard Business School Press.

Ledeneva, Alena V. 1998. Russia's Economy of Favours: Blat, Networking and Informal Exchange, Cambridge: CUP.

Lieb-Doczy, Enese E. (2000): Transition to Survival: Enterprise Restructuring in Twenty East German and Hungarian Companies, Ashgate, forthcoming.

Lieb-Doczy, Enese E. and Klaus E. Meyer (2000): Context Sensitivity of Post Acquisition Restructuring: An Evolutionary Perspective, Working Paper, Center for East European Studies, Copenhagen Business School, April.

Liebermann and Montgomery (1998): First-mover (dis)advantages: retrospective and link withthe resource-based view, Strategic Management Journal 19, p. 1111-1125.

Lyles, Marjorie A. and Inga S. Baird (1994): Performance of International Joint-Ventures in Two Eastern European Countries: The Case of Hungary and Poland, Management International Review 34, p. 313-329.

Lyles, Marjorie A., Nancy M. Carter and Inga S. Baird (1996): New Ventures in Hungary: The impact of U.S. Partners, Management International Review 36, p. 355-370.

Lyles, Marjorie A. and Jane E. Salk (1996): Knowledge Acquisition from Foreign Parents in International Joint Ventures: An Empirical Examination in the Hungarian Context, Journal of International Business Studies 27, p. 877903.

Maier, Charles S. (1997): Dissolution: The Crisis of Communism and the End of East Germany, Princeton, Princeton University Press.

Marinova, Svetla (2000): ***, PhD thesis, Faculty of Business and Economics, Copenhagen Buisness School.

Martin, Roderick (1999): Transforming Management in Central and Eastern Europe, Oxford: Oxford University Press. Marton, Katherin (1993) Foreign Direct Investment in Hungary, Transnational Corporations 2, p. 111-134.

Mattson, Lars-Gunnar (1992): The Role of Marketing for the Transformation of a Centrally Planned Economy to a Market Economy, in. H.C. Blomqvist, C. Görnroos and L.J. Lindqvist, eds.: Economics and Marketing: Essays in Honour of Gösta Mickwitz, Helsinki: Svenska Handelshögskolan, p. 181-96.

McCarthy, Daniel and Sheila M. Puffer (1997): Strategic Investment Flexibility for MNE Success in Russia: Evolving Beyond Entry Modes, Journal of World Business 32, p. 293-319. 
McMillan, Carl H. (1993): The Role of Foreign Direct Investment in the Transition from Planned to Market Economies, Transnational Corporations 2, p. 97-119.

McMillan, Carl H. (1994): Foreign Investment in Russia: Soviet Legacies and Post-Soviet Prospects, Occasional Paper no. 5, Centre for Research on Canadian-Russian Relations at Carleton University, Ottawa.

Meschi, Pierre-Xavier (1997): Longevity and cultural differences of international joint ventures: Toward time-based cultural management, Human Relations 50, p. 211-228.

Meyer, Klaus E. (1995): Foreign Direct Investment in the early Years of Transition: A Survey, Economics of Transition 3, p. 301-320.

Meyer, Klaus E. (1997): International Market Entry: Beyond Markets and Hierarchies, Working Paper, Center for East European Studies, Copenhagen Business School.

Meyer, Klaus E. (1998a): Direct Investment in Economies in Transition, Aldershot: Elgar.

Meyer, Klaus E. (1998b) Enterprise Transformation and Foreign Investment in Eastern Europe, Journal of East-West Business 4, p. 7-28.

Meyer, Klaus E. (2000a): Direct Investment in East Asia and in Eastern Europe: A Comparative Analysis, in P.ArtisienMaksimienko and M. Rojec, eds.: Direct Investment in Eastern Europe, London: Macmillan.

Meyer, Klaus E. (2000b): International Production Networks in Central Europe, Comparative Economic Studies 62, no. 1 , forthcoming.

Meyer, Klaus E. (2000c): Enterprise Transformation as Coordination Game: The Leadership Challenge, Working paper no. 33, Center for East European Studies, Copenhagen Business School, May.

Meyer, Klaus E. and Saul Estrin (1998): Opportunities and Tripwires for Foreign Investors in Eastern Europe, Thunderbird International Business Review 40, p. 209-234.

Meyer, Klaus E. and Saul Estrin (1999): Entry Mode Choice in Emerging Markets: Greenfield, Acquisition and Brownfield, CISME Working Paper no. 51, London Business School, January.

Meyer, Klaus E. and Inger Bjerg Møller (1998): Managing Deep Restructuring: Danish Experiences in Eastern Germany, European Management Review 16, p. 411-21.

Meyer, Klaus E. and Christina Pind (1999): The Slow Growth of Foreign Direct Investment in the Successor States of the Former Soviet Union, Economics of Transition 7, p. 201-214.

Meyer, Klaus E., Ane Tind and Maar Klinge Jacobsen (1999): National Internationalization Processes: Danish Businesses in the East, Academy of International Business Conference, Charlston, SC, November.

Michailova, Snejina, (1997) Inertia: Organizational Culture of Bulgarian Industrial Companies between Stability and Change, Ph.D. thesis 6/97, Faculty of Economics and Business, Copenhagen Business School.

Michailova, Snejina (2000): Planning Change in Russian Companies with Foreign Participation: Problems and Challenges faced by Western Expatriates, Academy of Management Executive, forthcoming, November.

Michailova, Snejina and Alla Anisimova (1999): Russian Voice from a Danish Company, Business Strategy Review, 10, p. $65-78$

Mueller, Stephen L. and L.D. Clarke (1998): Political Economic Context and Sensitivity to Equity: Differences between the United States and the Transition Economies of Central and Eastern Europe, Academy of Management Journal 41, p. 319-329.

Murrell, Peter (1990): The Nature of Socialism: Lessons from East European Foreign Trade, Princeton: PUP.

Murrell, Peter (1992): The Evolution in Economic and the Economic Reform of the Centrally Planned Economies, in: C. C. Clague and G. Rausser (eds): The Emergence of Market Economies in Eastern Europe, Cambridge, MA: Blackwell, p. 35-53. 
Mygind, Niels (1999): Enterprise Governance in Transition - a Stakeholder Perspective, mimeo, Copenhagen Business School. Working paper no. 30, Center for East European Studies, Copenhagen Business School, December.

Naujoks, Petra and Klaus-Dieter Schmidt (1994): Outward Processing in Central and East European Transition Countries: Issues and Results from German Statistics, Kiel Working Papers no. 631, Kiel Institute of World Economics.

Neale, C.W. and D. Shipley (1990): Empirical Insights into British Countertrade with Eastern Bloc Countries, International Marketing Review 7, no. 1, p. 15-31.

Nellis, John (1999): Time to Rethink Privatization in Transition Economies? Washington, DC: World Bank/IFC Working Paper no. 38.

Nelson, Joan, Chales Tilly and L. Walker, eds (1998): Transforming Post Communist Political Economies, Task Force on Economies in Transition, Nnational Research Council, Washington, DC: National Academy Press.

Newman, Karen (1998): Radical versus Incremental Change: The Role of Capabilities, Competition and Leaders, in: D. Denison, ed.: Managing Organizational Change in Transition Economies.

Newman, Karen and Stabley Nollen (1998): Radical Organizational Change, Thousand Oaks: Sage.

Nohria, Nitin and R. Gulati (1996): Is Slack Good or Bad for Innovation? Academy of Management Journal 39, p, 124564.

North, Douglas (1981): Structure and Change in Economic History, New York: Norton.

North, Douglas (1990): Institutions, Institutional Change and Economic Performance, Cambridge: Cambridge University Press.

Newman, Karen L. and Stanley D. Nollen (1998): Managing Radical Organizational Change: Company Transformation in Emerging Market Economies, Thousand Oaks, CA: Sage.

Obloj, Krystof and Howard Thomas (1996): Transforming State-owned Companies into Market Competitors in Poland, European Management Journal 16, no. 4, p. 390-399.

Organisation for Economic Cooperation and Development, OECD (1995): Assessing Investment Opportunities in Economies in Transition, Paris: OECD.

Offe, Claus (1995): Designing Institutions for East European Transitions, in: J. Hausner, B. Jessop and K. Nielsen, eds.: Strategic Choice and Path Dependency in Post-Socialism: Institutional Dynamics in the Transformation Process, Cheltenham: Elgar, p. 47-66.

Ozawa, Terutomo (1992): Foreign Direct Investment and Economic Development, Transnational Corporations 1, p. 27-54.

Parish, W. and E. Michelson (1996): Politics and Markets: Dual Transformations, American Journal of Sociology 101, p. $1042-1059$.

Peiperl, Maury and Saul Estrin (1997): Managerial Markets in Transition in Central and Eastern Europe: A Field Study and Implications, International Journal of Human Resource Management 8.

Pellegrin, Julie (1998): Market Linkages and the Dynamics of Regional Integration in Europe: Theoretical Considerations and Empirical Evidence at the Macroeconomic Level, in: B. Bastida, ed.: Integrating the Enterprise Sphere of Centraleuropean Countries in Transition into European Corporate Structures, ACE project No. 95P2003-R. Printed by Grup d'Anàlisi de la Transició Econòmica, Universidad de Barcelona, p. 61-76.

Peng, Mike W. 1997. Firm growth in transitional economies: Three longitudinal cases from China: 1989-96, Organization Studies 18, p. 385-413.

Peng, Mike W. 2000. Business Strategies in Transition Economies, Thousand Oaks, CA: Sage.

Peng, Mike W. and P.S. Heath. 1996. The Growth of the firm in Planned Economies in Transition: Institutions, Organizations, and Strategic Choice, Academy of Management Review 21, p. 492-528. 
Perotti, Enrico C. and Serhat E. Guney (1993): The Structure of Privatization Plans. Financial Management 22, p. 84-98. Puffer, Sheila M. (1996): Business and Management in Russia, Cheltenham: Elgar.

Puffer, Sheila and Daniel McCarthy. 1995. Finding the Common Ground in Russian and American Business Ethics, California Management Review 37, p. 29-46.

Puffer, Sheila M., Daniel J. McCarthy and Alexander I. Naumov (1997): Russian Managers Beliefs about Work: Beyond Stereotypes, Journal of World Business 32, p. 258-276.

Puffer, Sheila M., Daniel J. McCarthy and Alexander I. Naumov (2000): The Russian capitalist experiment, Cheltenham: Elgar.

Pye, Robert (1998): Foreign Direct Investment in Central Europe, Experiences of Major Western Investors, European Management Journal 16, p. 378-389.

Rona-Tas, A. (1994): The First shall be Last? Entrepreneurship in Communist Cadres in the Transition from Socialism, American Journal of Sociology 100, 40-69.

Rose, Richard, W. Michler and C. Haerpfer (1997): Getting Real: Social Capital in Post-Socialist Societies, Glasgow: Strathclyde University - CSPP.

Salmi, Asta (1996): Russian Networks in Transition: Implications for Managers, Industrial Marketing Management 25, p. 37-45.

Salmi, Asta (1999): Entry into Turbulent Business Networks: The Case of a Western Company on the Estonian Market, European Journal of Marketing 34.

Salmi, Asta and Kristian Møller (1994): Business Strategy during dramatic environmental change: A Network approach for analysing firm-level adaptation to the Soviet economic reform, P. Buckley and P. Ghauri, ed.: The Economics of Change in East and Central Europe, London: Academic Press.

Schuh, Arnold (2000): Global standardization as a success formula for marketing in Central Eastern Europe? Journal of World Business, May/June, forthcoming.

Schuh, Arnold, John C. Anderson and Michael J. Houston (1996): Marketing Strategies in East Central Europe: A Balancing Act between Globalization and Local Market Responsiveness, in: P. Chadraba and R. Springer, eds: Proceedings of the $4^{\text {th }}$ Annual Conference on Marketing Strategies for Central and Eastern Europe, Vienna: Wirtschaftsuniversität Wien.

Schuh, Arnold and Reiner Springer (1997): Marketing in Central and Eastern Europe: An Assessment of Past and Future Research, in: P. Chadraba and R. Springer, eds: Proceedings of the $5^{\text {th }}$ Annual Conference on Marketing Strategies for Central and Eastern Europe, Vienna: Wirtschaftsuniversität Wien.

Schwartz, Andrew and John Zysman, eds. (1998): Enlarging Europe: The Industrial foundations of a New Political Reality, Berkely: BRIE and Vienna: Kreisky Forum.

Seabright, P., ed. (2000): The Vanishing Rouble: Barter and Currency Substitution in Post-Socialist Societies, Cambridge: CUP, forthcoming.

Shama, A. 1992. Transforming the Consumer in Russia and Eastern Europe. International Marketing Review, 9(5): 43-59.

Sharma, Avraham (1995): Entry Strategies of U.S. Firms to the Newly Independent States, Baltic States and East European Countries, California Management Review 37, no. 3. p. 90-109.

Shekshnia, Stanislav (1998): Managing People in Russia: Challenges for Foreign Investors, European Management Journal 12, p. 298-305.

Smith, Stephen C., Beom-Cheol Cin and Milan Vodopivec (1997): Privatization Incidence, Ownership Forms and Firm Performance: Evidence from Slovenia, Journal of Comparative Economics 25, p. 158-179. 
Sorge, Arndt 1993. Arbeit, Organisation und Arbeitsbeziehungen in Ostdeutschland, Berliner Journal fuer Soziologie 4, 549-567.

Soulsby, Anna and Ed Clark (1996): The Emergence of Post-Communist Management in the Czech Republic, Organisation Studies 17, p. 227-248.

Spicer, Andrew, Gerry McDermott and Bruce Kogut (2000): Entrepreneurship and Privatization in Central Europe: The Tenuous Balance between Destruction and Creation, Academy of Management Review, forthcoming.

Stark, D. (1992): Path Dependence and Privatization Strategies in East Central Europe, East European Politics and Society 6, p. 17-54.

Stark, D. (1996): Recombinant Property in East European Capitalism, American Journal of Sociology 101, p. 993-1027.

Stiglitz, J. 1999. Whither reform? Ten years of the transition. Washington: World Bank Annual Conference on Development Economics.

Svetličič, Marjan, Matja Rojec and Andreja Trtnik (1999): Outward Foreign Investment by Central European Firms and Restrcucturing: The Case of Slovenia, Academy of International Business Conference, Charlston, SC, November.

Swaan, Wim (1997): Knowledge, Transaction Costs and the Creation of Markets in Post-Socialist Economies, in: P.G. Hare and J. Davis, eds: Transition to the Market Economy, Vol. II, London and New York: Routledge, p. 5376.

Sztompka, Pjotr (1993): Civilizational Incompetence: The Trap of Post-Communist Societies, Zeitschrift für Soziologie 22, no. 2, p. 85-95.

Taplin, and Frege (1999): Managing Transitions: The Reorganization of Two Clothing Manufacturing Firms, Organization Studies 20, p. 721-740.

Todeva, Emanuela (1999): Models for Comparative Analysis of Culture: The Case of Poland, International Journal of Human Resource Management 10, p. 606-623.

Todeva, Emanuela (2000): Comparative Business Network in Eastern Europe, Journal of East West Business.

Thomson, Neil and Carla Millar (1999): The Role of Slack in Transforming Organisations, mimeo, FH Nuremberg and City University London.

Thomson, Neil and McNamara (1998): ***, Journal of East European Management Studies

Thornton, J. and N.N. Mikheeva 1996: The Strategies of Foreign and Foreign-Assisted Firms in the Russian Far East: Alternatives to Missing Infrastructure, Comparative Economic Studies 38, no. 4, p. 85-120.

van Tulder, Rob and Winfried Ruigrok (1998): International Production Networks in the Auto Industry: Central and Eastern Europe as the Low End of the West European Car Complexes, in: A. Schwartz and J. Zysman, eds.: Enlarging Europe: The Industrial foundations of a New Political Reality, Berkely: BRIE and Vienna: Kreisky Forum.

Uhlenbruck, Klaus and Julio de Castro (1998): Privatization from the Acquirer's Perspective: A Mergers and Acquisitions Model, Journal of Management Studies 35, p. 619-640.

Uhlenbruck, Klaus and Julio de Castro (2000): Foreign Acquisitions in Central and Eastern Europe: Outcomes of Privatization in Transitional Economies, Academy of Management Journal, forthcoming.

Uhlenbruck, Klaus and Klaus Meyer (2000): Organizational Transformation in Transition Economies: Resource-based and Organizational Learning Perspectives, mimeo, Texas A\&M University.

UN - United Nations (annually): World Investment Report, Geneva: UN.

Urban, Waltraut (1992): Economic Lessons for the East European Countries from Two Newly Industrializing Countries in the Far East? Wiener Institut für International Wirtschaftsvergleiche, Forschungsberichte no. 182.

Vickers and Yarrow (1991): Privatization ***, Journal of Economic Perspectives. 
Villinger, Roland (1996): Post-acquisition Managerial Learning in Central East Europe, Organization Studies 17, p. 181206.

Vlachotsicos, Charalambos (1998): Russian Communitarianism: An Invisible Fist in the Transformation Process in Russia. Working paper no. 120, William Davidson Institute, University of Michigan Business School, January.

Vlachoutsicos, Charalambos and Paul R. Lawerence (1996): How Managerial Learning can assist Economic Transformation in Russia, Organization Studies 17, p. 311-326.

Webster, L. and J. Charap (1993): The Emergence of Private Sector Firms in St. Petersburg: A Survey of Firms, World Bank Technical Paper, no. 228, Washington, DC: World Bank.

Whitley, Richard, ed. (1992): European Business Systems, London: Sage.

Whitley, Richard and Laslo Czaban (1998a): Institutional Transformation and Enterprise Change in an Emerging Capitalist Economy: The Case of Hungary, Organisation Studies 19, p. 259-280.

Whitley, Richard and Laslo Czaban (1998b): Ownership, Control and Authority in Emergent Capitalism: Changing Supervisory Relations in Hungarian Industry, International Journal of Human Resource Management 9, p. 99-115.

World Bank (1996): World Development Report: From Plan to Market, Washington, DC: Oxford University Press.

Wright, Mike, Robert E. Hoskisson, Igor Filatochev and Trevor Buck (1998): Revitalizing privatized Russian Enterprises, Academy of Management Excecutive 12, no. 2, p. 74-85.

Wright, Mike, Steven Thompson and Ken Robbie (1993): Finance and Control in Privatisation by Management Buy-out, Financial Accountability and Management 9, no. 2, p. 75-99. 


\section{Endnotes:}

1. Readers interested in comprehensive reviews of economic transition are recommended to consult Lavigne (1999) as well as reviews comission by multilateral institutions (e.g. World Bank 1996, Fisher and Sahay 2000, EBRD annually). Independent studies are published e.g. in the Journal of Comparative Economics, Economics of Transition, and Comparative Economic Studies. This author maintains a website with information on recent research and links: http://www.econ.cbs.dk/institutes/cees/

2. Concise surveys of recent trends of FDI are provided by EBRD (annually), and UN (annually). For a critical evaluation of the data see Brewer (1994), Meyer (1995) and Meyer and Pind (1999).

3. The empirical evidence on performance implications is hotly debated as many Western advisors see it as a key obstacle to restructuring (e.g. Havrylyshyn and Gettigan 1999). Several studies suggest that manager-ownership outperforms employee ownership (e.g. Frydman et al. 1997). Yet other studies find positive effects of employee ownership compared to dispersed shareholding or state-ownership on production efficiency (Smith $e t$ al. 1997, Jones and Mygind 1999b), on labour productivity (Earle and Estrin 1997, Djankov 1999b), and on product, input and asset restructuring (Estrin and Rosevear 1999).

4. On the nature of firms in the real existing socialism see for instance Berliner (1952), Kornai (1980, 1992) and Lawrence and Vlachoutsicos 1990).

5. A starting point may be the series of short research notes on transition economies in the Journal of Small Business Management in 1995 to 1997. 